\title{
SEJARAH SINGKAT GRHA SABHA PRAMANA UGM DARI KHAZANAH ARSIP UNIVERSITAS GADJAH MADA
}

\author{
Heri Santosa, A.Md., S.S.T., Ars. \\ Universitas Gadjah Mada \\ (herisantosa@ugm.ac.id)
}

\section{INTISARI}

Penelitian ini bertujuan menyajikan informasi tentang sejarah Auditorium UGM, sehingga memudahkan para peneliti maupun pengguna arsip dalam menemukan arsip berdasarkan tema tertentu. Sumber penelitian ini meliputi sumber primer dan sekunder berupa khasanah arsip statis yang ada di Arsip UGM, wawancara serta bahan pustaka. Metode yang dipakai dalam penelitian ini adalah metode penelitian sejarah. Gedung Auditorium UGM berdiri tegak dihamparan lahan seluas 11.069,80 meter persegi. Lahan itu, sebelumnya dikenal sebagai lapangan Pancasila. Gedung Auditorium UGM diresmikan dengan sengkalan memet yang berbunyi Catur Kumuda Ambuka Bawana: 1994. Arti sengkalan memet ini adalah bahwa UGM didirikan tahun 1949 dan peresmian Auditorium UGM pada tahun 1994, dengan harapan semoga seluruh sivitas akademika UGM selalu mendapatkan keberuntungan dan kebahagiaan di dalam tugas dan pengabdiannya demi nusa dan bangsa Indonesia. Awalnya fungsi utama Gedung Auditorium UGM digunakan untuk menunjang segala kegiatan akademik yang diselenggarakan oleh Universitas Gadjah Mada tetapi seiring berjalannya waktu gedung ini sekarang bisa dimanfaatkan oleh masyarakat umum dalam bentuk sewa.

Kata kunci: arsip, Arsip UGM, Auditorium UGM, Grha Sabha Pramana.

\section{ABSTRACT}

This study aims to present information about the history of UGM Auditorium, making it easier for researchers and archives users to find archives based on specific themes. The source of this research includes primary and secondary source sources in the form of static archive repository in University Archive of UGM, interviews and library materials. The method used in this research is the method of historical research. UGM Auditorium stands upright on a land area of 11,069.80 square meters. The land, formerly known as the Pancasila field. UGM Auditorium Building was inaugurated by memet disclosure which reads Catur Kumuda Ambuka Bawana: 1994. The meaning of this memet is that UGM was established in 1949 and the inauguration of Auditorium UGM in 1994, hoping that all UGM academicians will always get luck and happiness in their duties and his devotion for the sake of the nation and the nation of Indonesia. Initially the main function of UGMAuditorium Building was used to support all academic activities organized by Universitas Gadjah Mada but over time this building can now be utilized by the public in the form of rent.

Keywords: archives, Auditorium UGM, Grha Sabha Pramana, University Archive of UGM. 


\section{PENGANTAR}

\section{Latar Belakang Masalah}

UGM sebagai universitas nasional dan memiliki bayak mahasiswa, sudah sewajarnya kalau memiliki Gedung Auditorium yang bisa mewadahi kegiatan sivitas akademika UGM. Keinginan untuk memiliki bangunan berkapasitas besar itu semula untuk menampung acara wisuda yang setahun empat kali. Sebelum memiliki Gedung Auditorium, acara wisuda dilakukan di serambi Kantor Pusat UGM, yaitu Balairung dengan memasang tenda besar. Awalnya gedung ini rencananya hanya digunakan untuk acara wisuda. Namun seiring berjalannya waktu, Auditorium dengan corak arsitektur gaya Mataram ini juga diproyeksikan untuk konferensi bertaraf nasional dan untuk registrasi mahasiswa semester baru maupun untuk keperluan administrasi Ujian Masuk Perguruan Tinggi Negeri (UMPTN) (Berita Kagama, November 1993).

Fungsi Gedung Auditorium UGM direncanakan untuk menampung kegiatan intern UGM, kegiatan wisuda dengan daya tampung 5.000 orang, kegiatan rapat dengan daya tampung 800 orang, dan kegiatan upacara bendera di halaman alun-alun Auditorium. (Laporan Perancangan Pekerjaan Pembangunan Gedung Auditorium Proyek Peningkatan Perguruan Tinggi P2T-UGM, 1993). Untuk mengatasi masalah diatas, UGM mulai membangun Gedung Auditorium UGM pada tanggal 1 Mei 1993 yang terletak di sebelah Selatan Gedung Perpustakaan UGM, tepatnya di lapangan Pancasila. Bangunan tiga lantai berbentuk joglo dengan ornament ukiran gaya Yogyakarta ini memiliki luas lantai $11.069,80 \mathrm{~m}^{2}$ (Warta UGM.Agustus 1993).

\section{Rumusan Masalah}

Tulisan ini disusun sebagai upaya untuk memberikan solusi untuk mempermudah peneliti untuk menemukan arsip berdasarkan tematis sehingga arsip bisa ditemukan berdasarkan tema tertentu. Secara garis besar, topik masalah yang dirumuskan adalah bagaimana sejarah proses pembangunan gedung Auditorium UGM dan perkembangan pemanfaatan gedung ini bagi sivitas akademika UGM maupun masyarakat umum. Penulis berusaha menyajikan informasi tentang sejarah Gedung Auditorium UGM dari rintisan awal hingga sekarang melalui rubrik telisik ini. Tulisan ini dibuat berdasarkan hasil perpaduan antara studi pustaka, penelusuran, dan penelitian arsip dari beberapa khasanah arsip yang tersimpan di Arsip UGM serta wawancara dengan narasumber terkait.

Penelitian ini membatasi pencarian sumber sejarah pada sumber asli dan sumber primer hanya dari khasanah arsip statis yang ada di Arsip UGM. Pembatasan penelitian ini akan berakibat penyajian penulisan sejarah kurang lengkap, namun Penulis berusaha menyajikan informasi tentang sejarah gedung ini sehingga memudahkan para peneliti maupun pengguna arsip dalam menemukan arsip berdasarkan tema tertentu.Penyajian informasi arsip tentang suatu hal berdasarkan tema tertentu atau suatu peristiwa dalam bidang kearsipan disebut sebagai guide tematis, sehingga penelitian ini bisa disebut juga menyajikan guide tematis tentang sejarah singkat Gedung Auditorium UGM dan perkembangannya. 


\section{Tujuan Penelitian}

Tujuan dan manfaat penelitian ini adalah sebagai berikut:

1. Mengetahui sejarah proses pembangunan dan perkembangan pemanfaatan Gedung Auditorium UGM

2. Mengetahui ketersediaan khasanah arsip yang ada di Arsip UGM terkait Gedung Auditorium UGM

3. Memudahkan para peneliti maupun pengguna arsip dalam menemukan informasi terkait sejarah Gedung Auditorium UGM.

\section{Metodologi Penelitian}

Tulisan ini merupakan penelitian sejarah tentang sejarah singkat Gedung Auditorium UGM. Metode yang digunakan di dalam penelitian ini adalah deskriptif, dengan teknik pengumpulan data terhadap sumber asli dan sumber primer berupa khazanah arsip statis yang ada di Arsip UGM, wawancara dengan narasumber yang terkait dan bahan pustaka yang relevan.

\section{Kerangka Pemikiran}

Kerangka pemikiran dalam tulisan ini, penulis berusaha memadukan antara teori dari buku-buku yang relevan dan sumber primer berupa arsip statis yang ada di Arsip UGM. Mempelajari sejarah adalah mempelajari masa lalu. Seringkali kita mendengar ungkapan 'Belajarlah dari sejarah', Adanya kemiripan peristiwa sejarah yang pernah terjadi pada masa lalu dengan peristiwa sejarah yang terjadi pada masa masa sesudahnya. Sejarah adalah hal yang harus didokumentasikan dan diwariskan pada generasi selanjutnya. (Hasanah, 2016:06).
Sejarah akan lebih efektif sebagai proses pembelajaran apabila tidak hanya sekedar dibaca tetapi dikaji dan diteliti (Kanumoyoso, 2017:5). "Tanpa kombinasi sejarah dan teori kita tidak mungkin bisa memahami masa lalu maupun masa kini" (Burke, 2003:27).

Sejarah juga memberikan nilai guna kesenangan (rekreatif) bagi mereka yang mempelajarinya (Munajat, 2004:5). Sejarah tidak hanya memiliki nilai guna secara teoritis, tetapi juga memiliki kegunaan praktis. Kegunaan sejarah secara praktis dapat dibagi dua yaitu tujuan secara intrinsik dan ekstrinsik. Secara intrinsik, sejarah berguna untuk pengetahuan. Secara intrinsik ada empat guna sejarah yaitu sejarah sebagai ilmu, sejarah sebagai cara mengetahui masa lampau, sejarah sebagai pernyataan pendapat, dan sejarah sebagai profesi (Kuntowijoyo 2001: 20). Dalam penulisan sejarah dengan pendekatan multidimensional, disiplin sejarah merupakan disiplin pokok. Meskipun demikian, tidaklah menghalangi dipergunakannya konsep-konsep dan metodemetode ilmu-ilmu bantu guna memperkaya dan memperdalam kisah sejarah (Kartodirdjo, 1982:66). Ibarat seorang pemahat, bila ia membuat patung besar mempergunakan pahatan besar, tetapi bila patung itu kecil dan rumit, maka ia membutuhkan pahatan-pahatan yang kecil dan renik pula (Kartodirdjo, 1982: vii). Jadi, alat haruslah sesuai dengan produk yang hendak dihasilkan.

Arti kata bangunan dalam Kamus Besar Bahasa Indonesia adalah sesuatu yang didirikan atau sesuatu yang dibangun seperti rumah atau gedung dan sebagainya. Sedangkan menurut Geddes dan Grosset (2003:9), bangunan atau 
dalam bahasa Inggrisnya building adalah sesuatu yang dibangun dengan dinding dan atap. Bila dikaitkan dengan kata sejarah, menurut Feiden (1994: 2), bangunan bersejarah merupakan sesuatu yang memberikan kita rasa ingin mengetahui lebih banyak mengenai orang-orang dan kebudayaan yang menghasilkan bangunan tersebut. Sedangkan Menurut Alan (1978:5 ), bangunan bersejarah adalah produk karya seni hasil dari pemikiran kreatif, bagian dari rantai perkembangan arsitektur, hasil perkembangan teknologi, salah satu cara hidup suatu zaman, dan berkaitan erat dengan suatu masyarakat atau peristiwa sejarah. Koentjaraningrat menggambarkan karya arsitektur sebagai salah satu wujud paling kongkret dari kebudayaan, sebagai bagian dari kebudayaan fisik yang sifatnya nyata dari benda-benda mulai dari kancing baju, peniti, sampai ke komputer dan alat-alat elektronik yang serba canggih (Koentjaraningrat, 1974:20). Arsitektur Grha Sabha Pramana (GSP) sebagai salah satu proyek infrastruktur unggulan di kampus UGM. Karakternya mengusung langgam modern yang tampak kaku, bersih, simetris untuk komposisi badannya yang berpadu dengan beberapa elemen arsitektur Joglo seperti struktur atap dan konstruksi sakaguru di dalamnya (Pembangunan Gedung Auditorium UGM, 1993:2-3).

Lembaga kearsipan dan arsiparis mempunyai peran strategis dalam menyajikan informasi arsip. Masih banyak informasi arsip yang tersimpan di lembaga kearsipan belum ditelili, diungkap dan diketahui oleh masyarakat umum. Sehingga antara sejarawan, lembaga kearsipan, dan arsiparis harus bersinergi untuk mengungkap data sejarah dan membentuk jaringan informasi penulisan sejarah serta tukar menukar informasi (Kuntowijoyo, 1994:101).

\section{PEMBAHASAN}

\section{Perancangan Gedung Auditorium UGM}

Keberhasilan sebuah proyek konstruksi diawali dan sangat ditentukan dengan berhasil tidaknya untuk menyusun landasannya, yaitu berupa perancangan yang lengkap dan matang. Adapun proses pembangunan Auditorium UGM ini ada beberapa konsep antara lain:

\section{Konsep Perancangan Gedung}

Pembuatan dokumen perancangan Gedung Auditorium UGM sebenarnya telah selesai pada tahun 1986 yang mengacu kepada Rencana Induk Pengembangan (RIP) UGM tahun 19821992. Walaupun sudah diajukan sejak lama, persoalan terbentur pencairan dana. Dana 75 persen dari Loan Bank Dunia XXI tidak segera cair. Dana tersebut baru cair sekitar pertengahan April 1993, begitu dana dari Bank Dunia XXI cair, maka dana yang berasal dari pemerintah juga segera turun. Setelah dana turun, kontrak kerjasama segera dilakukan di bulan Mei 1993 dan pembangunan Gedung Auditorium segera dimulai.

Menurut Pimpro P2T (Proyek Peningkatan Perguruan Tinggi) UGM, Drs. Muhammad Munandar dalam buku laporan Tim Pengelola Pembangunan Fisik P2T UGM tahun 1993 menyebutkan bahwa bangunan yang menelan biaya 9,069 milyar itu direncanakan selesai pada bulan Mei 1994. Bangunan berbentuk joglo dengan ornament ukiran khas Mataraman itu dibangun dengan luas lantai 11. 069,80 m2 termasuk tribun terbuka disebelah selatan menghadap lapangan menjadi $13.654 \mathrm{~m} 2$. 


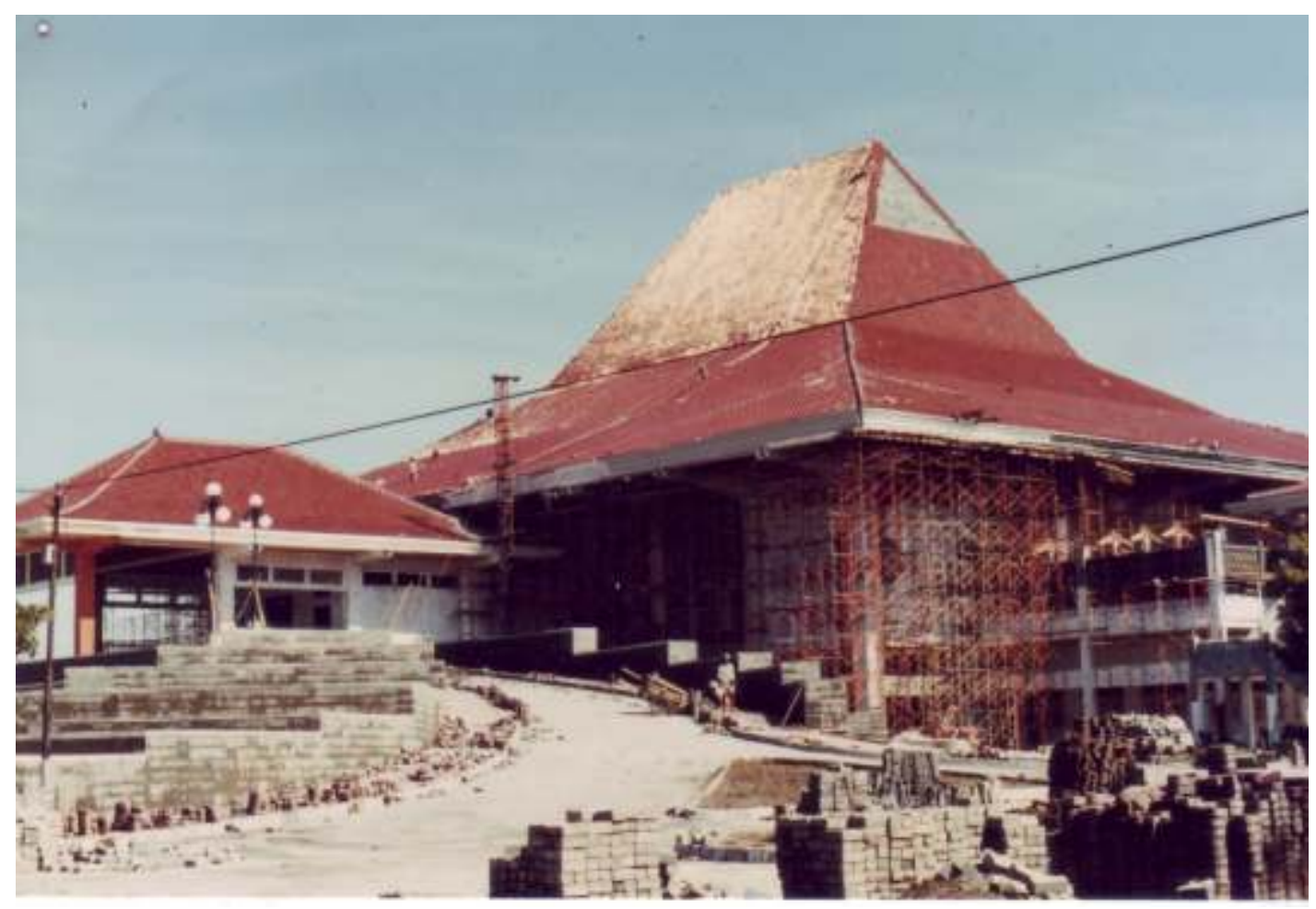

Foto 1

Gedung GSP yang belum jadi tampak dari depan sebelah kiri

(Sumber: AF3.IP.IG.1994.1G)

Perancangan Auditorium Universitas Gadjah Mada mencerminkan fungsional, efisien, menarik tetapi tidak berlebihan. Hasil perancangan gedung menyerasikan dengan lingkungan, pemakaian bahan, pemilihan warna dan ornament. Pemakaian bahan produksi dalam negeri dan tidak menekankan kemewahan material. Pemeliharaan bangunan diupayakan serendah mungkin. Desain bangunan harus menunjang pelaksanaan jangka waktu pendek dan dapat dimanfaatkan secepatnya (Laporan Tim Pengelola Pembangunan Fisik P2T Proyek Peningkatan Perguruan Tinggi UGM, 1993).

Keberhasilan suatu perancangan arsitektur bangunan tidak hanya didukung oleh sebuah konsep arsitektural yang matang tetapi juga memahami perancangan dari aspek-aspek yang lain seperti : pemilik proyek (klien), manajemen, teknologi bahan / material, multidisiplin, ekonomi dan bisnis, peraturan bangunan, anggaran biaya bangunan, dan jadwal proyek. (A m strophel13 a r chitect. 2013 . https://amstrophel13architect.wordpress.com/ 2013/04/24/hal-yang-perlu-diperhatikan-dalamproses-perancangan/diakses tanggal $18 \mathrm{Mei}$ )

Menurut Istimawan Dipohusodo Koordinator Bidang Pembangunan Gedung dan Prasarana Lingkungan Kampus Proyek Peningkatan Perguruan Tinggi UGM, ada beberapa kendala yang dihadapi ketika melakukan sebuah perancangan gedung antara lain kendala teknologi, keuangan, sosial, bahkan politik misalnya, yang baru terungkap dan disadari bersifat menghambat terhadap berlangsungnya proses perancangan. Atau kemungkinan yang lain lagi, diakibatkan oleh munculnya pandangan baru sebagai hasil investigasi dan penelitian yang lebih rinci, yang 
menuntut rumusan ulang atas masalah yang dihadapi. Sebagai contoh simulasi proses pengujian terhadap hasil dari suatu tahap perencanaan konstruksi, yang mana hasil pengujian tersebut sekaligus dijadikan landasan tahap perencanaan berikutnya yang bersifat lebih mendetail, yang nantinya akan diuji. Dengan demikian proses perancangan ini membutuh kemampuan yang berupa pengalaman, intuisi dan kecerdikan dari seorang perencana (Dipohusodo Istimawan, 1996:278-279).

Menurut teori perancangan sebuah gedung, proses perancangan pembangunan Gedung Auditorium UGM mengalami kendala di bidang keuangan, karena dana 75 persen dari Loan Bank Dunia XXI tidak segera cair, sehingga proses pembangunan gedung Auditorium UGM mundur selama 7 tahun dari jadwal yang telah direncanakan.

\section{Konsep Filosofis Master Plan UGM}

Menurut Ir. Soegeng Djojowirono, Ketua Tim Pengelola Pembangunan Auditorium UGM dalam buku laporan Tim Pengelola Pembangunan Fisik P2T (Proyek Peningkatan Perguruan Tinggi) UGM tahun 1993 menyebutkan bahwa Auditorium senilai hampir 10 milyar ini menjadi bagian terdepan, dari dua bangunan lainnya yaitu Perpustakaan dan Gedung Pusat UGM. Ir Soegeng menjelaskan, falsafah bangunan dan penataan massa bangunan merupakan konsep arsitektur Jawa di daerah pusat kampus dengan urutan hierarki sebagai berikut: Alun-alun (sisa lahan di depan Auditorium), Pendopo (Auditorium), Pringgitan (Perpustakaan), dan Dalem (Kantor Pusat UGM). Ketiga gedung tersebut sebagai posisi sentral dan mencerminkan karakter kampus

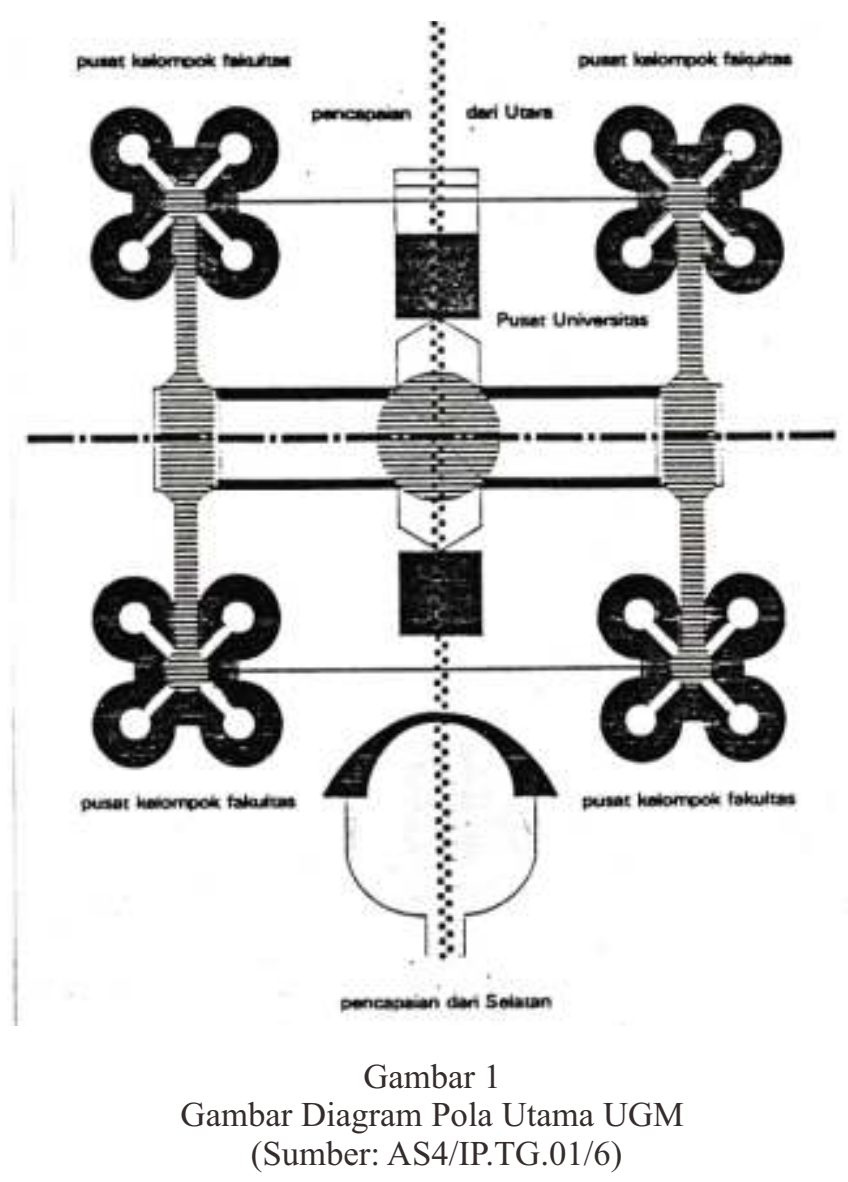


UGM, kesatuan yang kuat kompak, berwibawa dan monumental. Bangunan Auditorium akan menegaskan arah masuk kampus dari pusat kota, dengan memperjelas poros Boulevard kampus dari arah Selatan. Kesatuan diwujudkan dengan menciptakan kontak yang mudah antar bagianbagian dari Universitas. Tiap-tiap fakultas dikelompokkan dan berpusat di pusat-pusat kelompok fakultas yang saling berhubungan.

\section{Konsep Modul}

Konsep modul perencanaan berdasarkan Dokumen Laporan Perancangan Pekerjaan Pembangunan Gedung Auditorium UGM tahun 1991, menyebutkan bahwa Pengembangan modul rancangan 0.60 meter, dengan memperhatikan faktor-faktor: ukuran manusia, menentukan efektifitas dan besar kecilnya suatu ruang, daya tampung dan volume ruang secara horizontal (ruang gerak), dan secara vertikal (sudut pandang). Ukuran furniture dan ukuran elemen penutup lantai (finishing) menentukan penggunaan dan pemilihan modul dari suatu bangunan.

Penataan ruang Auditorium dengan data tampung 5000 orang, dipilih bentuk bangunan Joglo. Skala bangunan dengan bentang dari sisi kiri ke sisi kanan bangunan adalah 57,5 meter, dan ketinggian bangunan sekitar 39 meter dari permukaan tanah. Penyusunan tata ruang gedung Auditorium berdasarkan fleksibilitas ruang, jumlah pengunjung yang vareatif dapat ditampung pada ruang yang sesuai dengan kapasitasnya, dan dengan perhitungan sudut pandang pengunjung kearah panggung secara melebar.
Konsep penataan ruang Auditorium UGM memiliki dua kebutuhan yaitu untuk memenuhi kebutuhan bagi sivitas akademika UGM dan kebutuhan bagi masyarakat luar. Dari dua kebutuhan ini maka timbulah sebuah pendekatan fleksibilitas ruang, karena ruang dalam gedung, khususnya ruang auditorium nantinya akan dibuat untuk berbagai jenis kegiatan, yang membutuhkan sebuah fleksibilitas agar memudahkan perubahan suatu ruang tanpa mengurangi kualitasnya.

Menurut Julius Panero dan Marten Zelnik praktisi arsitektur, desainer interior, sekaligus associate professor pada Fashion Institut Technology di New York, perencanaan ruangruang merupakan masalah yang rumit dan kompleks, yang melibatkan faktor-faktor seperti volume aliran (yang didefinisikan dalam besaran jumlah pejalan kaki per satuan kaki lebar jalan per menit), waktu dan jarak maju ke depan yang ditempuh, kecepatan jalan, serta panjang antrian. Biasanya dibutuhkan jasa seorang insinyur teknik sipil transportasi atau spesialis perancang jalur pejalan kaki untuk merancang ruang sirkulasi yang lebih tepat (Panero \& zelnik, 2003: 268)

Perancangan konsep modul pembangunan gedung Auditorium UGM telah memenuhi syarat pembangunan sebuah gedung, karena dilaksanakan oleh ahli dibidangnya yaitu Ir. Istimawan dipohusodo penulis buku Manajemen Proyek dan Konstruksi. Selain itu Istimawan juga menjabat sebagai Koordinator Bidang Pembangunan Gedung dan Prasarana Lingkungan Kampus Proyek Peningkatan Perguruan Tinggi UGM. Dalam hal ini bukunya juga sebagai referensi dalam membuat tulisan ini. 


\section{Perancangan Arsitektur Gedung}

Proses perancangan arsitektur gedung dalam praktek profesional dikelola melalui tahapan sebagai berikut :

\section{Concept Design (Konsep Perancangan)}

Menjabarkan keinginan pemilik proyek dari menjadi kerangka acuan kerja sehingga dapat dipahami tim perancang atau menjabarkan kerangka acuan kerja yang sudah ada dari pemilik proyek dan melakukan studi awal rancangan.

- Membuat konsep perancangan mulai dari program ruang sampai dengan sketsa sketsa, berupa alternatif-alternatif yang bisa dipilih pemilik proyek.

\section{Schematic Design (Perancangan Skematik)}

- Mewujudkan konsep / gagasan dalam gambar skematik site lokasi, denah, bentuk bangunan (tampak) dan outline spesifikasi yang akan digunakan dalam pengembangan, pada tahap ini disiplin lain seperti struktur dan M/E sudah memberikan arahannya.

- Membantu pemilik proyek dengan membuat rancangan yang masih dalam batasan anggaran (dibantu Quantity Surveyor).

- Membantu pemilik proyek dengan membuat rancangan yang marketable (untuk bangunan komersial) sesuai saran konsultan.

- Memahami peraturan-peraturan yang berkaitan dengan rancangan / proyek dan proses perijinan serta berkonsultasi dengan pihak-pihak yang terkait.

\section{Design Development (Pengembangan}

\section{Rancangan)}

Mewujudkan rancangan skematik dalam skala yang lebih jelas dan detail, semua kebutuhan antar disiplin sudah terakomodasi.

Mengkoordinasi tim perancang dengan basis pengetahuan komperehensif untuk mengantisipasi kemungkinan-kemungkinan permasalahan yang timbul pada proses pembuatan gambar kerja.

- Berkoordinasi pemilik proyek serta pihakpihak yang terkait dengan perijinan atau pihak konsultan spesialis lain yang ditunjuk.

- Memperjelas outline spefisifikasi sesuai bagian bangunan yang dirancang dan penjelasan mengenai sistem dan peralatan pada bangunan.

\section{Construction Documentation (Dokumen}

\section{Konstrusi / Pelaksanaan)}

- Menyelesaikan gambar kerja yang telah terkoordinasi multidisiplin dan mengembangkan detail konstruksi untuk mewujudkan rancangan dalam detail-detail teknis

- Memahami pengetahuan standar gambar kerja yang dipahami semua pihak.

- Menyusun detail spefisifikasi teknis atau rencana kerja \& syarat-syarat (RKS) sesuai bagian bangunan yang dirancang.

- Mengkoordinasikan penyiapan dokumen pelaksanaan dan memonitor proses persiapan dokumen lelang / tender (gambar, spesifikasi, BQ).

(Amstrophel13architect, 2013. Seputar Arsitektur https://amstrophel13architect. wordpress.com/2013/04/24/proses-design/; diakses tanggal 18 Mei 2018)

Berdasarkan konsep perancangan arsitektur gedung, Posisi tampak Gedung 
Auditorium secara filosofis memiliki nilai monumental. Pendaerahan (zoning) tampak disesuaikan dengan urutan dari arah Selatan kearah Utara. Alun-alun, berupa lapangan dan pelataran upacara dengan bentuk lingkaran dan pusat tiang bendera. Daerah penerima ke Auditorium, sebagai main entrancel penerima tamu utama terletak ditengah, antara Alun-alun dan Gedung Auditorium dan pada ketinggian (level) lantai II. Komposisi dan tata massa bangunan Gedung Auditorium merupakan massa tunggal. Tata massa gubahan simetris kanan kiri. Pintu masuk samping berupa dua buah regol berada di sisi Barat dan Timur, mengungkapkan konsep pekarangan dan pintu masuk rumah tinggal tradisional Jawa (Dokumen Laporan Pembangunan Gedung Auditorium UGM, 1993).

Pencapaian utama umum pada bangunan Auditorium memperkuat nilai monumental, terletak pada lantai dua sebelah Selatan. Pintu masuk bangunan utama mengungkapkan penonjolan berupa kuncungan yang lebih kuat sebagai aksen massa tambahan pada bagian depan tengah. Pencapaian dari jalan samping yang terletak di Selatan bangunan pada lantai I. Kapasitas parkir kendaraan pada halaman parkir sekitar 130 kendaraan dengan sistem serong bersudut 45 derajad. Dalam kondisi yang sangat padat maka dapat ditambah dengan parkir parallel di tepi jalan sehingga kapasitas menjadi lebih besar (Dokumen Laporan Pembangunan Gedung Auditorium UGM, 1993).

Proses perancangan arsitek gedung Auditorium tersebut perlu memperhatikan 3 pertimbangan yaitu gedung auditorium harus mampu menjadi landmark/bangunan yang mudah dikenal di kawasan yang akan berkembang, menjadi fasilitas publik yang saling bersinergi dengan kawasan sekitar, dan berdampak baik terhadap kawasan sekitar gedung auditorium tersebut sehingga keberadaan gedung auditorium ini bisa berfungsi secara maksimal bagi lingkungan disekitarnya.

\section{Tata Ruang dan Daya Tampung}

Menurut Dokumen Laporan Pembangunan Gedung Auditorium UGM tahun 1993 menyebutkan bahwa untuk menampung jumlah pengunjung sebanyak 5.000 orang, dilakukan penambahan ruang pada sayap kiri dan sayap kanan Gedung Auditorium.

Adapun kapasitas masing-masing ruangan sebagai berikut:

$\begin{array}{ll}\text { Ruang Auditorium } & : 1.508 \text { orang } \\ \text { Balkon } & : 1.342 \text { orang } \\ \text { Sayap kiri } & : 1.081 \text { orang } \\ \text { Sayap kanan } & : 1.081 \text { orang } \\ \text { Jumlah } & : 5.012 \text { orang }\end{array}$

Luas lantai Auditorium

1. Lantai dasar seluas

Ruang rapat $: 4.328,20 \mathrm{~m}^{2}$

Ruang kantor : $777,60 \mathrm{~m}^{2}$ $: 1.233,20 \mathrm{~m}^{2}$ dan selebihnya toilet, pantry, gudang, selasar, hall dan ruang tangga.

2. Lantai dua seluas $: 4.535,90 \mathrm{~m}^{2}$ Terdiri atas: hall : $265,00 \mathrm{~m}^{2}$ Ruang Auditorium dan Selasar: 1.821,90 m² Panggung : $191,10 \mathrm{~m}^{2}$ Sayap Barat, (hall dan tangga) : $869,10 \mathrm{~m}^{2}$ Sayap Timur (hall dan tangga) : $809,10 \mathrm{~m}^{2}$ Selebihnya untuk ruang rias, ruang alat, selasar, panggung, ruang tangga dan selasar.

3. Lantai tiga seluas $: 2.205,70 \mathrm{~m}^{2}$ Toilet, selasar, ruang tangga $\quad: \quad 908,70 \mathrm{~m}^{2}$ Balkon : $963,60 \mathrm{~m}^{2}$ Hall Total luas lantai $\frac{: 108,40 \mathrm{~m}^{2}}{11.069,80 \mathrm{~m}^{2}}$ Selebihnya untuk ruang proyektor, ruang control, gudang dan ruang tangga. 


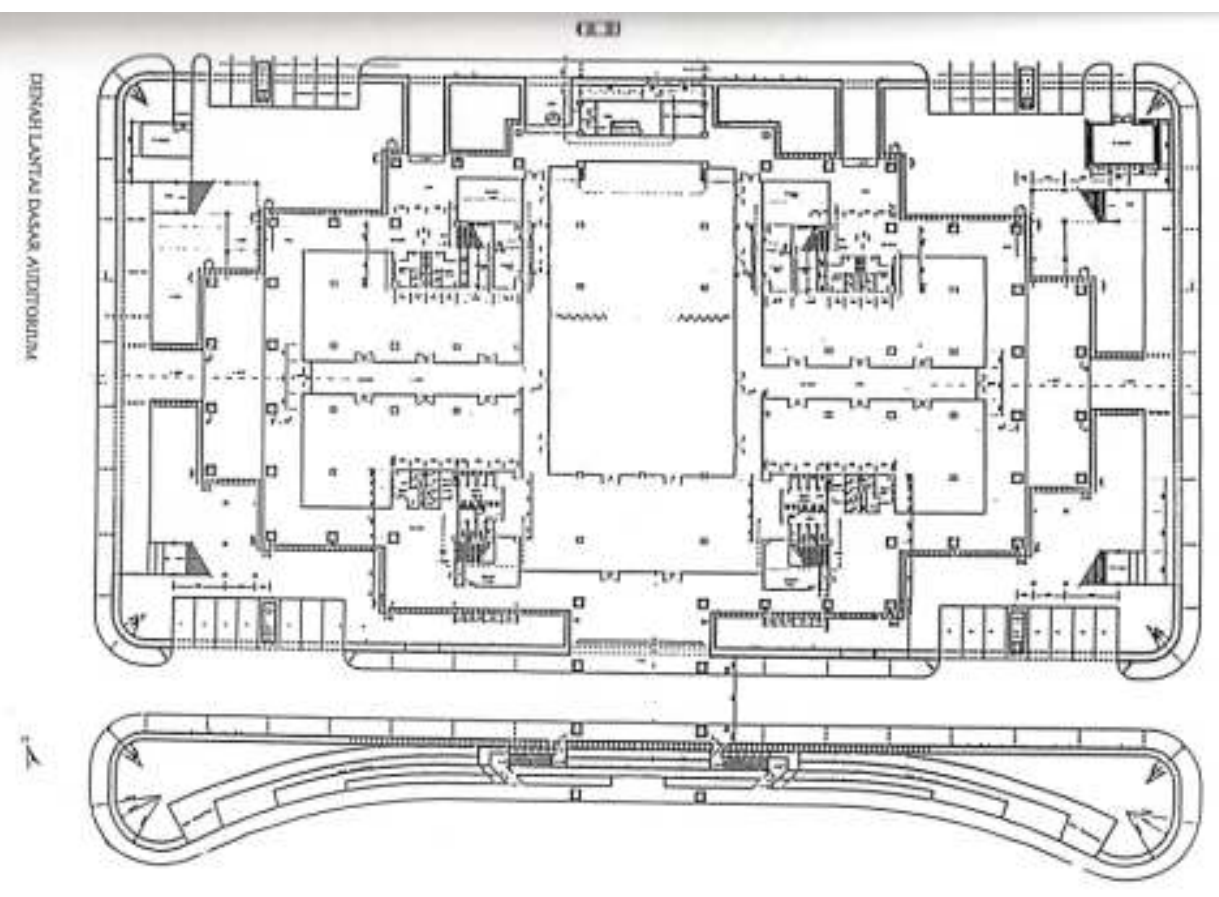

Gambar 2

Denah Lantai Dasar Gedung Auditorium UGM

(Sumber: AS4/IP.TG.01/6)

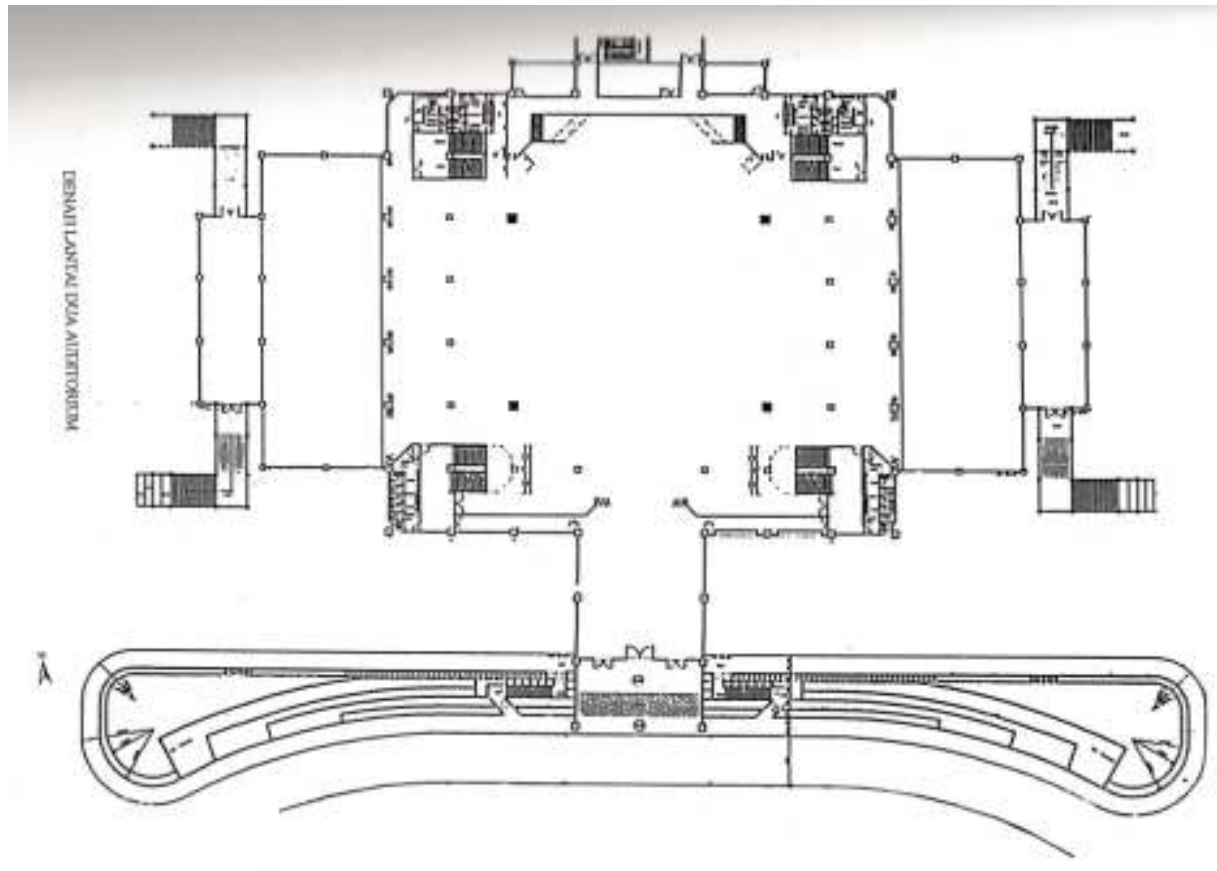

Gambar 3

Gambar Denah Lantai 2 Gedung Auditorium UGM

(Sumber: AS4/IP.TG.01/6) 


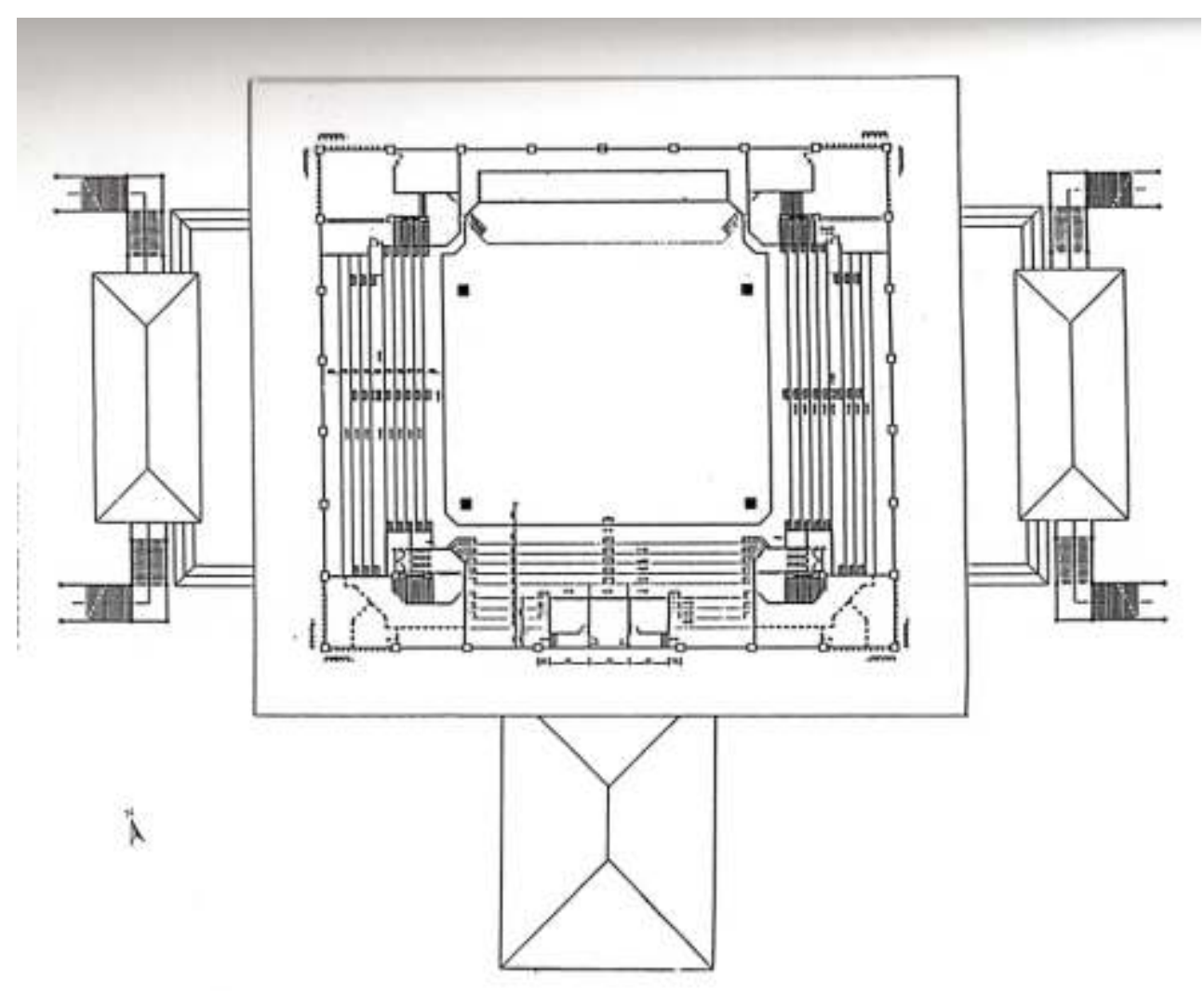

Gambar 4

Denah Tempat Duduk Lantai 3 Gedung Auditorium UGM

(Sumber: AS4/IP.TG.01/6)

\section{Bentuk Bangunan dan Landscape}

Bentuk bangunan Auditorium UGM merupakan pendopo yang diungkapkan dalam bentuk Joglo sinom, mempunyai atap tiga susun, yaitu brunjung, penanggap dan penitik. Karakter bangunan tradisional diperkuat dengan stilisasi dari bentuk yang asli, antara lain: hiasan praba dan wajikan pada kolom, bentuk umpak, susunan balok tumpangsari, dan garis-garis profil yang merupakan stilisasi dari bentuk tradisional. Rencana pengolahan lansekape tersebut atas beberapa bagian. Rencana penghijauan, meliputi: jalan utama, daerah tamu (main entrance), alun-alun dan sekitar bangunan. Rencana bangunan pengkerasan meliputi: taman parkir, jalan pedestrian, pelataran tiang bendera. Rencana perabot taman meliputi: lampu taman, lampu dinding, tempat duduk (Dokumen Laporan Pembangunan Gedung Auditorium UGM, 1993).

Penataan ruang terbuka tersebut di lengkapi dengan taman vegetasi dan taman air / kolam air. Penataan taman dan vegetasi diwujudkan dengan penataan yang teratur dan menyesuaikan kondisi tapak. Ini dimaksudkan agar munculnya keharmonisan dengan lingkungan alam sekitar. 


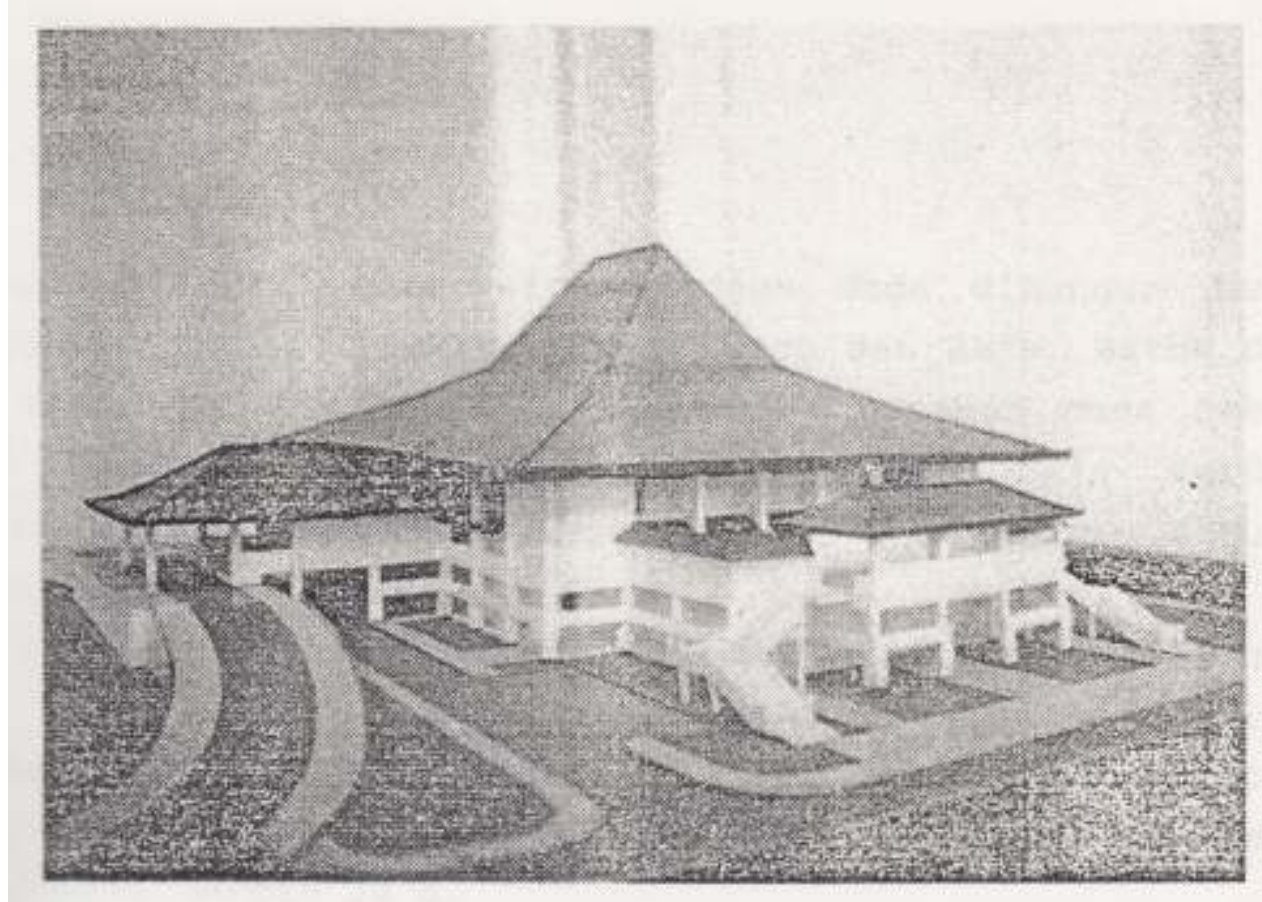

Gambar 5

Gambar Maket Gedung Auditorium UGM

(Sumber: AS4/IP.TG.01/6)

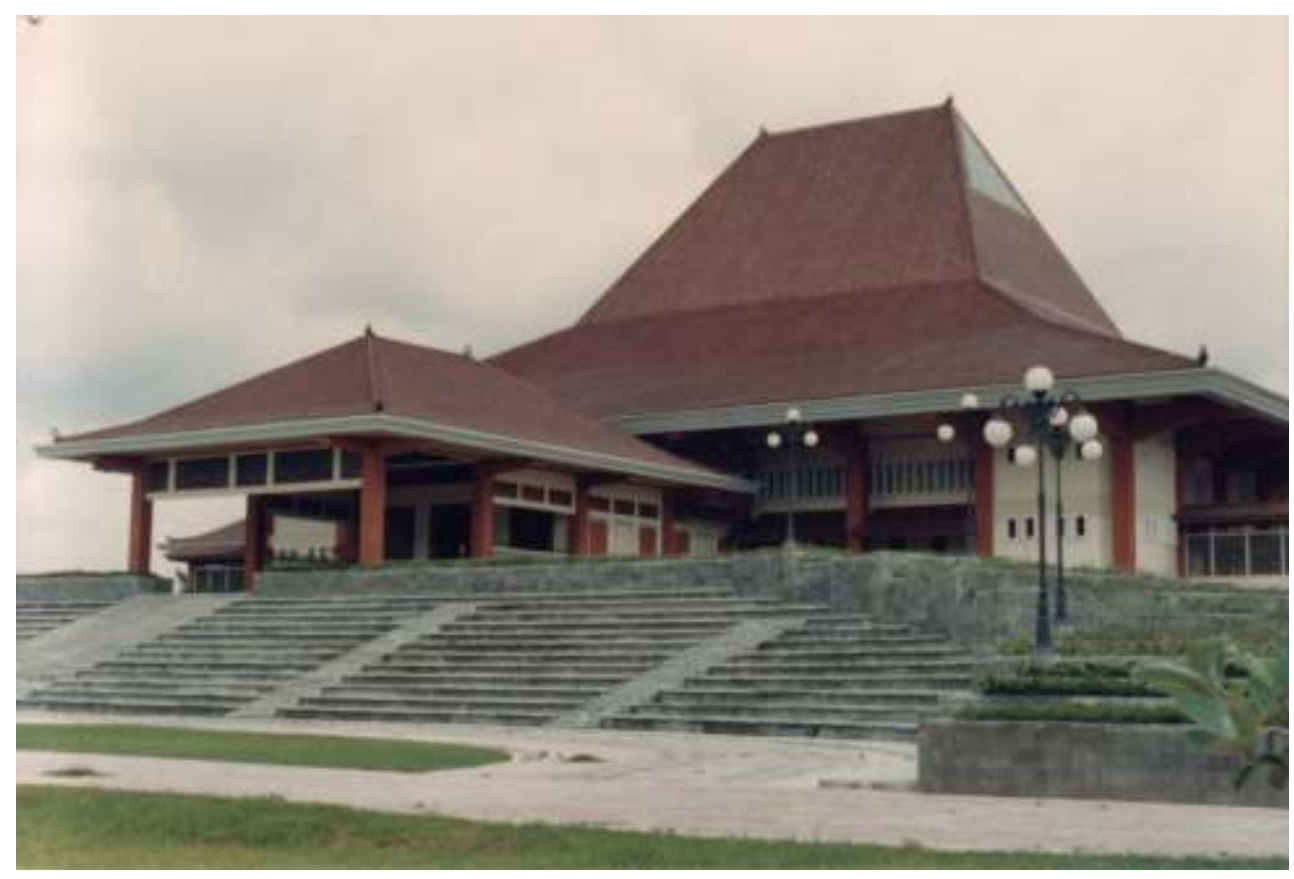

Foto 2

Foto gedung GSP tampak dari depan samping kanan

(AF3/IP.IG/1995-2A) 


\section{Hiasan Kanan Kiri Jalan menuju ke Ruang Utama}

Pada pintu masuk kanan kiri di lantai 2 di hias dengan ukiran motif gaya Yogyakarta dengan stilisasi tumbuh-tumbuhan dan bungabungaan menggambarkan kehidupan yang berkembang. Ukiran motif pohon hayat gubahan gaya lung-lungan dengan bunga teratai sertai berbagai bunga dan buah-buahan melambangkan kehidupan yang sejahtera dan bahagia (Laporan Tim Pengeloa Pembangunan Fisik P2T Proyek Peningkatan Perguruan Tinggi UGM, 1993).

Berdasarkan data foto riil yang diambil oleh penulis, antara desain awal ukiran pintu lantai 1 dengan foto riil ukiran pintu lantai 1 berbeda. Sedangkan ukiran pintu masuk kanan kiri lantai 2 memakai desain Ukiran pintu lantai 1, tetapi desain pintunya juga berbeda. Desain pintu dan ukiran serta simbul-simbul tersebut dibuat dengan harapan supaya pegawai maupun lulusan UGM bisa mengembangkan ilmunya sehingga dalam kehidupannya diberikan kebahagiaan dan kesejahteraan dimanapun mereka berada.

\section{Elemen Hias pada Bangunan Teras Lantai Dua}

Desain ukiran pintu masuk utama (tengah) lantai dua bagian depan, dihias ukir tembaga dengan motif bagian tengah symbol UGM mengandung sengkalan yang mempunyai arti berdirinya UGM, yaitu tahun 1949. Di kanan kiri terdapat motif stilisasi dari burung garuda serta bunga teratai. Motif garuda dalam mitologi jawa mempunyai arti lambing keperkasaan, kejayaan, kebebasan dan kesaktian. Sedangkan bunga teratai dilambangkan sebagai ibu bumi yang melambangkan kesuburan/kemakmuran. Apabila dirangkai secara keseluruhan, motif yang dipakai sebagai elemen hias mempunyai arti berdirinya Universitas Gadjah Mada harus melahirkan sarjana yang perkasa dalam arti intelektual dan moralnya harus mencerminkan kecerdasan yang dilandasi "budi luhur laku utomo" didalam melakukan pengabdiannya untuk mensejahterakan/ memakmurkan rakyat/bangsa Indonesia (Laporan Tim Pengelola Pembangunan Fisik P2T Proyek Peningkatan Perguruan Tinggi UGM, 1993).

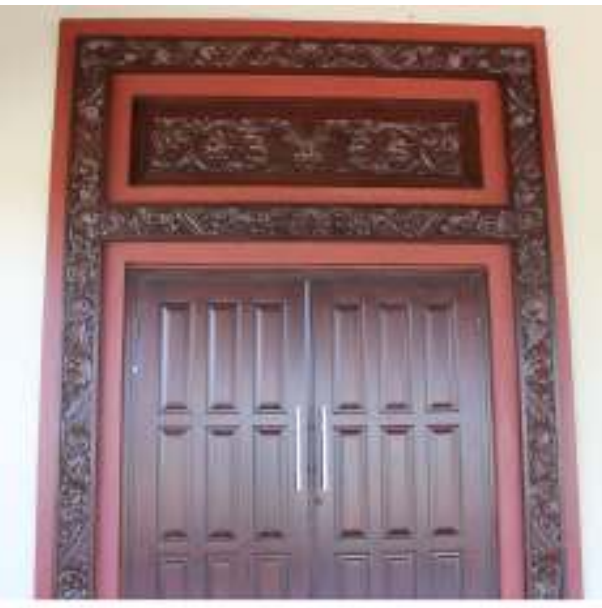

Foto 3

Foto Ukiran Pintu masuk kanan kiri Lantai 2 Gedung Auditorium UGM Fotografer: Heri Santosa

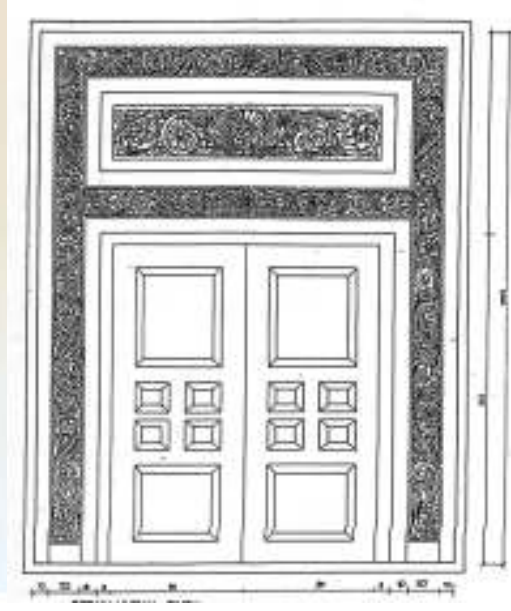

Gambar 6

Desain Ukiran Pintu Lantai 1 Gedung Auditorium UGM (Sumber: AS4/IP.TG.01/6)

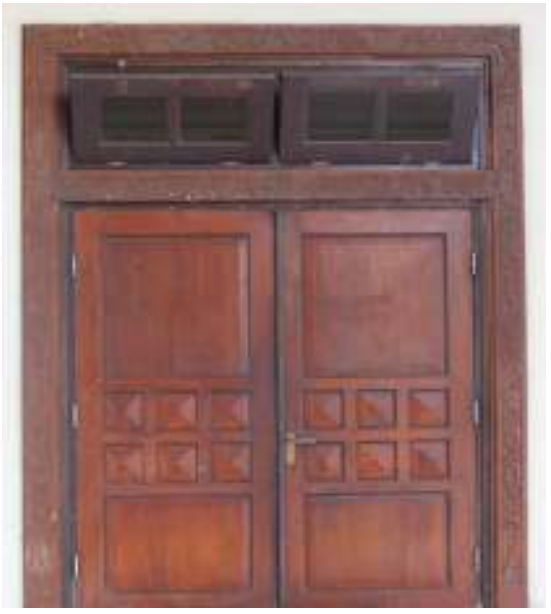

Foto 4

Foto Ukiran Pintu lantai 1 Gedung Auditorium UGM Fotografer: Heri Santosa 


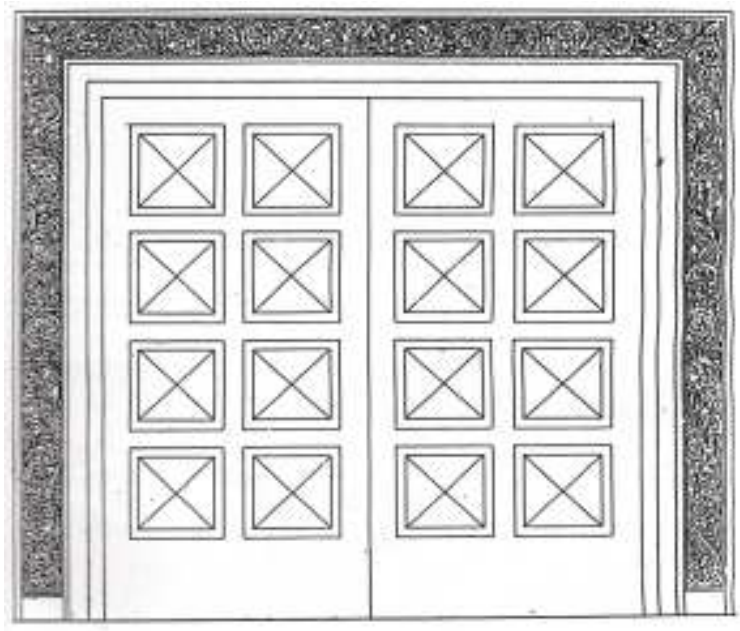

Gambar 7

Desain Ukiran Pintu Lantai 2 Gedung Auditorium UGM (Sumber: AS4/IP.TG.01/6)

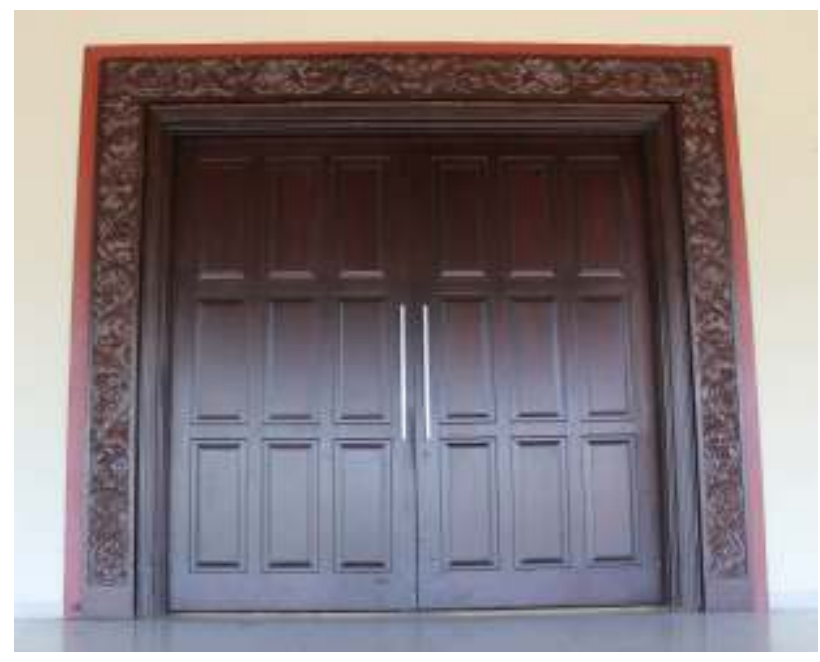

Foto 5

Foto Ukiran Pintu Lantai 2 Gedung Auditorium UGM Fotografer: Heri Santosa

Berdasarkan perbandingan gambar dan foto diatas, desain ukiran gawang pintu sama tetapi desain pintunya ada perbedaan dengan desain awal. Namun ukiran yang ada pada gawang pintu terlihat sangat indah dan desainnya sampai sekarang bisa mengikuti perkembangan zaman. Dilihat dari ukiran yang dibuat pada bagian pintu Auditorium UGM ini, menunjukkan bahwa UGM memiliki visi, misi, dan harapan kedepan yang jelas yang digambarkan dalam simbulsimbul tersebut.

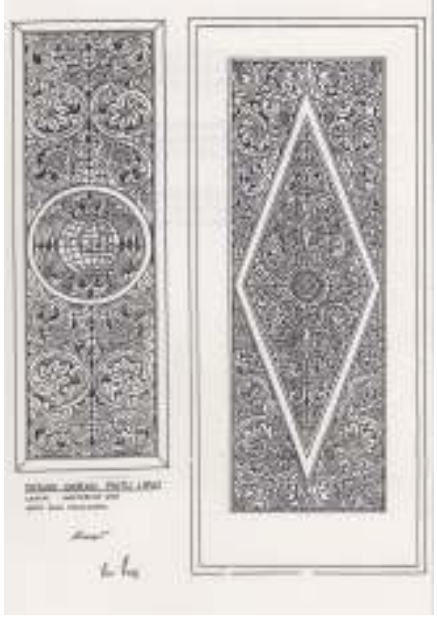

Gambar 8

Desain Ukiran Pintu Lipat Gedung Auditorium UGM Lantai 2

(Sumber: AS4/IP.TG.01/6)

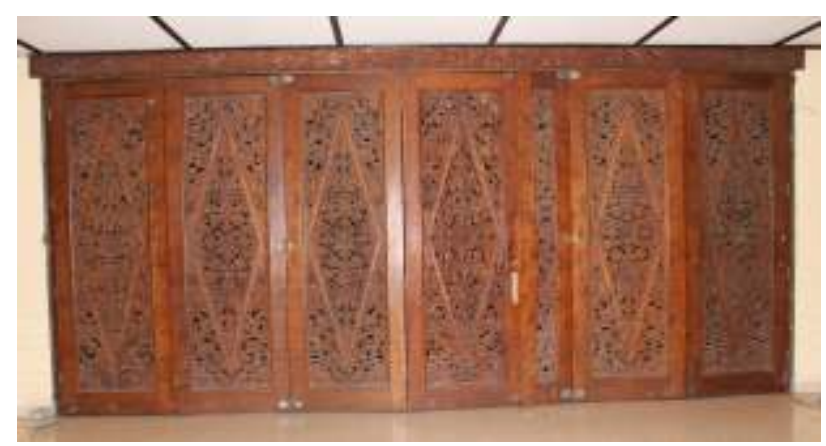

Foto 6

Foto Ukiran Pintu Lipat Gedung Auditorium UGM Lantai 2 Fotografer; Heri Santosa

\section{Elemen Hias pada Pintu Lipat}

Ukiran yang ada di pintu lipat adalah menggubah unsur pohon hayat yang distilir dalam gaya motif Yogyakarta dengan ceplok bunga mekar dan lung-lungan dengan bunga kuncup dan setengah mekar serta buah. Arti dari motif ini melambangkan tumbuh, berkembang, berbuah diartikan: Tri Dharma Perguruan Tinggi, yakni pendidikan menumbuhkan semangat belajar mengejar agar dapat berkembang intelektualnya, sikapnya dan ketrampilannya sehingga hasil dari proses ini dapat berbuah untuk diabdikan /disumbangkan pada masyarakat Indonesia sehingga masyarakat adil 
dan makmur dapat tercapai (Laporan Tim Pengelola Pembangunan Fisik P2T Proyek Peningkatan Perguruan Tinggi UGM, 1993).

Berdasarkan foto terbaru yang diambil oleh penulis, desain ukiran pintu gambar 8 sebelah kanan sama dengan foto 6 tetapi desain pintu gambar 8 sebelah kiri tidak dipakai di ukiran pintu lipat Gedung Auditorium lantai 2. Desain pintu lipat ini terkesan sangat mewah dan ketika di buka tidak memakan tempat. Selain itu desain ukiran pintu lipat ini mempunyai filosofi bahwa UGM dari waktu kewaktu diharapkan selalu tumbuh dan berkembang dalam memajukan intelektual dan mencerdaskan bangsa Indonesia di dunia pendidikan sehingga tercapai masyarakat yang adil dan makmur.

\section{Elemen Hias pada Soko Guru, Dada Peksi, Singup, Panggung dan Dinding Akustik}

Berdasarkan laporan Tim Pengelola Pembangunan Fisik P2T Proyek Peningkatan Perguruan Tinggi UGM tahun 1993, bahwa motif pada soko guru melambangkan gunung atau bumi tempat berpijak. Motif sorot atau praba pada pengeret, dada peksi, tumpangsari melambangkan kebesaran, kewibawaan, dan kemuliaan. Singup motif ceplok dengan delapan sudut yang terdiri atas gubahan lung-lungan melambangkan delapan penjuru dunia atau delapan arah mata angin. Pengertian dari keseluruhan motif ini adalah melambangkan bahwa sesuai fungsi tempat adalah untuk wisuda para lulusan UGM dari tahun ke tahun diharapkan lulusan dalam mengabdikan dirinya berpijak pada bumi Indonesia sebagai tumpah darahnya untuk mencapai kebesaran bangsa

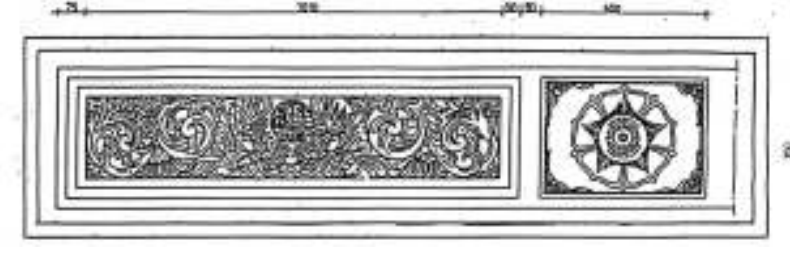

Gambar 9

Desain Ornamen Atas Panggung Gedung Auditorium UGM Lantai 2 (Sumber: AS4/IP.TG.01/6)

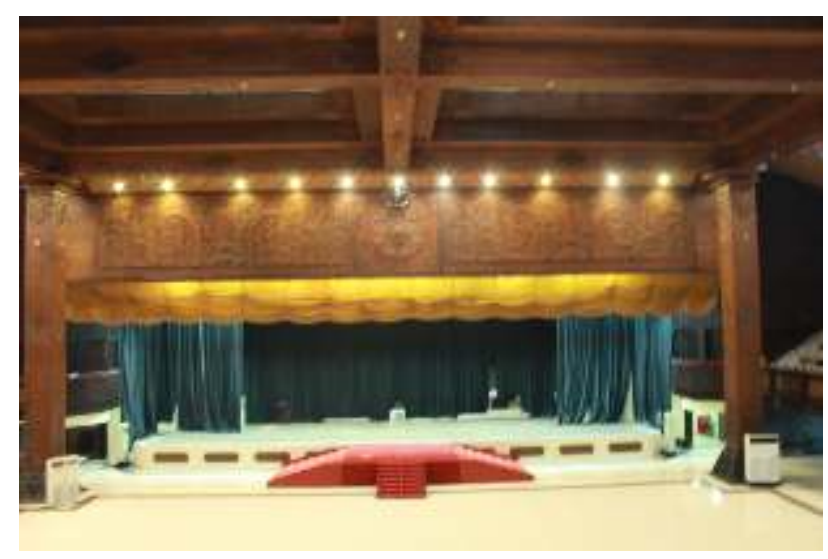

Foto 7

Foto Ornamen Atas Panggung Gedung Auditorium UGM Lantai 2 Fotografer; Heri Santosa

Indonesia yang gemanya dapat dipancarkan keseluruh delapan penjuru dunia.

Alas panggung dan dinding akustik dengan motif kalpataru adalah simbul lingkungan hidup, artinya seluruh sivitas akademika UGM didalam mengabdikan dirinya selalu berwawasan lingkungan hidup. Hiasan diatas panggung adalah sengkalan yang berbunyi catur kumuda ambuka bawana: 1994 dan kumuda catur ambuka: 1949. Arti sengkalan memet ini adalah bahwa UGM didirikan tahun 1949 dan peresmian Auditorium UGM pada tahun 1994. Di kanankiri sengkalan memet tumbuh lung-lungan lambing kemujuran dan kebahagiaan/ keberuntungan bagi kehidupan manusia.

Berdasarkan foto riil yang diambil oleh penulis, desain ornament gambar 9 dengan foto 7 sama 
dengan desain awal. Desain ornament panggung gedung Auditorium UGM lantai dua ini terkesan sangat kokoh dan sakral sehingga panggung ini digunakan untuk acara-acara resmi yang diselenggarakan baik oleh intern UGM maupun masyarakat umum.

\section{Pelaksanaan Pembangunan}

Ada beberapa tahapan yang dilakukan dalam pelaksanaan pembangunan gedung Auditorium UGM. Tahapan pelaksanaan pembangunan ini disusun sedemikian rupa mulai dari pengerjaan awal hingga finishing. Semuanya disusun didalam Time Schedule yang jelas sebelum pelaksanaan, sehingga proyek tersebut dapat berjalan sesuai rencana dan tepat waktu. Adapun bahan-bahan yang dibutuhkan dan tahapan pembangunan gedung Auditorium UGM sebagai berikut:

\section{Bahan Utama}

Berdasarkan buku laporan Tim Pengelola Pembangunan Fisik P2T (Proyek Peningkatan Perguruan Tinggi) UGM, 1993 menyebutkan bahwa gedung ini dibangun dengan menggunakan bahan struktur utama beton dan baja. Beton dengan kuat tekan karakteristik $225 \mathrm{~kg} / \mathrm{cm}^{2}$ digunakan pada sebagian besar struktur utama gedung ini. Bahan baja terdeform (deformed bar) dengan tegangan leleh 3900 $\mathrm{kg} / \mathrm{cm}^{2}$ digunakan sebagai tulangan pokoknya. Baja kuat tarik tinggi (high strength steel) dengan tegangan putus $180 \mathrm{KN} / \mathrm{cm}^{2}$ dan beton kuat tekan karakteristik $350 \mathrm{~kg} / \mathrm{cm}^{2}$ digunakan pada struktur balok-balok prategang purna tarik (post tensioned) yang memiliki bentangan sekitar $15 \mathrm{~m}$ sampai $30 \mathrm{~m}$.

\section{Struktur Bawah}

\section{a. Penyelidikan Tanah}

Sebelum membangun gedung Auditorium UGM, tahap pertama yang perlu dilakukan adalah penyelidikan tanah di lapangan (sondir dan bor). Tahapan ini memberikan informasi tanah cadas dengan daya dukung $150 \mathrm{~kg} / \mathrm{cm}^{2}$ pada kedalaman sekitar 4 meter di permukaan asli. Daya dukung tanah yang cukup baik yang terletak hanya pada kedalaman 1-2 meter memberikan alternative terbaik bagi pemakaian fondasi telapak dan lajur (spread and continuous footing) seperti yang digunakan pada gedung Auditorium UGM ini. Penyelidikan tanah ulang sudah di lakukan dibawah salah satu sokoguru untuk lebih memberikan keyakinan tentang daya dukung tanah dibawah lapisan cadas. Hasil penyelidikan tanah ulang mendukung hasil yang pernah dilakukan sebelumnya (Laporan Tim Pengelola Pembangunan Fisik P2T Proyek Peningkatan Perguruan Tinggi UGM, 1993).

\section{b. Fondasi}

Tahapan selanjutnya adalah membuat fondasi lajur yang menghubungkan kolomkolom utama untuk mendukung beban cukup besar sekitar ruang induk dan balkon. Hal ini bertujuan agar penurunan (settlement) setempat sedapat mungkin dikurangi. Fondasi telapak hanya digunakan untuk mendukung kolom dengan beban ringan. (Laporan Tim Pengelola Pembangunan Fisik P2T Proyek Peningkatan Perguruan Tinggi UGM, 1993)

Untuk menggali tanah keperluan membuat fondasi plat lebar dengan kedalaman cukup mungkin lebih baik menggunakan ekskavator, power shovel, atau dragline scaper. Sedangkan 
untuk penggalian yang lebih dalam lagi dapat menggunakan derek traktor dilengkapi dengan bakul (bucket) (Dipohusodo Istimawan, 1996: 369).

\section{Struktur Atas}

\section{a. Kolom, Balok dan Plat}

Menurut Laporan Tim Pengelola Pembangunan Fisik P2T (Proyek Peningkatan Perguruan Tinggi) UGM tahun 1993, menyebutkan bahwa penggunaan menara angkut (tower crane) pada pekerjaan Gedung Auditorium memudahkan dalam pengangkutan rakitan tulang kolom yang sebelumnya sudah dipersiapkan di suatu bengkel kerja. Disamping itu pengecoran beton kolom dapat pula dilakukan dengan mudah. Tidak seperti pada kolom, tulangan balok dan plat harus di rakit di tempat. Namun pengangkutan tulangan pokok dan pengecoran beton banyak dibantu oleh adanya Menara angkut.

Perakitan tulangan balok prategang dipersiapkan hati-hati agar posisi dan keadaan selubung kabel (duct) dapat diperiksa dengan cermat sebelum pengecoran beton, dan air semen tidak masuk ke dalam selubung kabel pada saat pengecoran beton. Kabel prategang ditarik pada saat beton berumur 2 minggu. Pada saat itu ternyata kuat tekan beton karakteristik sudah mencapai 95\% dari kuat tekan karakteristik rencana $\left(350 \mathrm{~kg} / \mathrm{cm}^{2}\right)$. Balok-balok prategang ini digunakan pada bentangan sekitar $15 \mathrm{~m}$ (entrance), 22 meter (hall) dan 30 meter (tie beam). Pelaksanaan plat balkon dilakukan dengan sistem pracetak (precast). Disamping sistem ini memberikan kemudahan pada pelaksanaan (didukung oleh adanya menara angkut), kualitas plat dilapangan dapat pula diawasi dengan mudah (Laporan Tim Pengelola Pembangunan Fisik P2T Proyek Peningkatan Perguruan Tinggi UGM, 1993).

\section{b. Rangka Atap}

Rangka atap Gedung Auditorium UGM terbuat dari rangka baja. Rangka baja (frame) dengan sistem hubungan las ini digunakan untuk mendukung atap genteng yang berada diatas ruang utama (hall). Sedang baja profil WF/I digunakan untuk mendukung atap genteng diatas balkon. Baja yang digunakan akan dilindungi terhadap korosi dengan bahan khusus. (Laporan Tim Pengelola Pembangunan Fisik P2T Proyek Peningkatan Perguruan Tinggi UGM, 1993).

\section{Mekanikal, Elektrikal dan Sanitasi \\ a. Mekanikal}

Gedung Auditorium dilengkapi dengan mesin pompa bersih dan hydrant untuk menunjang kebutuhan air bersih dan bahaya kebakaran. Kapasitas tendon air bawah tanah 75 $\mathrm{m}^{2}$ yang disuplai dari instalasi air bersih UGM. Sanitasi hydrant Gedung Auditorium dilengkapi dengan detektor asap maupun panas untuk mendeteksi lebih dini apabila akan terjadi kebakaran (Laporan Tim Pengelola Pembangunan Fisik P2T Proyek Peningkatan Perguruan Tinggi UGM, 1993).

\section{b. Elektrikal}

Sebuah Gedung Auditorium UGM yang besar tentunya butuh daya listrik yang cukup besar. Kebutuhan daya listrik terpasang sebesar 400 KVA disiplai dari PLN. Selain itu dilengkapi dengan emergency genset sebesar 163 KVA. 
Penerangan didalam gedung disesuaikan kebutuhan baik untuk ruang-ruang rapat dilantai dasar dan ruang Auditorium di lantai dua. Sedangkan penerangan di luar gedung diutamakan untuk keperluan keamanan dan sekaligus sebagai penerangan taman dan plaza. Selain penerangan buatan di dalam gedung, juga sudah direncanakan memanfaatkan penerangan alami. Untuk menampilkan Gedung Auditorium pada malam hari, direncanakan akan dipasang juga lampu sorot kearah bagian depan gedung. Sehubungan dengan keterbatasan dana maka sistem pendinginan ruang AC baru dilaksanakan instalasi listrik danducting. Untuk kelanjutan sistem pendinginan ruang dengan AC masih diperlukan tambahan dana (Laporan Tim Pengelola Pembangunan Fisik P2T Proyek Peningkatan Perguruan Tinggi UGM, 1993).

Gedung Auditorium ini juga dilengkapi dengan sound system untuk mendukung acaraacara yang diselenggarakan di Gedung Auditorium. Menurut rencana semula gedung ini dilengkapi dengan CCTV, tetapi berhubung keterbatasan dana maka yang diprioritaskan adalah pemasangan instalasi CCTV. Untuk memperlancar sistem komunikasi antar ruang didalam gedung dan antara gedung Auditorium dengan gedung-gedung lain dilingkungan kampus akan dipasang jaringan telepon yang dihubungkan dengan PABX di Kantor KPTU UGM. Mengingat ketinggian Gedung Auditorium yang tingginya sekitar 39 meter dari muka tanah, sesuai dengan peraturan yang baru maka dipasang penangkal petir 3 spit dan pada spit tengah dipasang lampu tanda ketinggian bangunan (Laporan Tim Pengelola Pembangunan Fisik P2T Proyek Peningkatan Perguruan Tinggi UGM, 1993).

\section{c. Sanitasi}

Seperti halnya gedung-gedung lain di kampus UGM sistem sanitasi yang ada mengikuti standar yang berlaku. Air kotor disalurkan melalui septick tank dan sumur peresapan pada beberapa tempat. Pembuangan air hujan dari gedung dan sekitar gedung disalurkan melalui sumur-sumur peresapan dan disalurkan ke saluran air hujan kampus yang ada (Laporan Tim Pengelola Pembangunan Fisik P2T Proyek Peningkatan Perguruan Tinggi UGM, 1993).

Berdasarkan data-data dan buku referensi dari Istimawan Dipohusodo yang berjudul manajemen Proyek dan Konstruksi, proses pembangunan Gedung Auditorium UGM ini sudah sesuai dengan buku referensi tersebut. Alasannya karena dalam proses pembangunan, Ir. Istimawan Dipohusodo juga berperan sebagai koordinator pembangunan Gedung Auditorium UGM. Jadi semestinya ilmu yang telah ditulis dalam bukunya diaplikasikan dalam proses pembangunan Gedung Auditorium UGM ini.

\section{Peresmian Gedung Auditorium UGM}

Gedung Auditorium UGM berdiri tegak dihamparan lahan seluas 11.069,80 meter persegi. Lahan itu, sebelumnya dikenal sebagai lapangan Pancasila. Gedung ini mulai dibangun pada tanggal 1 Mei 1993 dan selesai dibangun pada tanggal 8 September 1994 kemudian diresmikan oleh Presiden Soeharto pada tanggal 20 Desember 1994. Selanjutnya diserahterimakan dari Drs. Muhammad Munandar selaku pimpinan Proyek Peningkatan Perguruan Tinggi UGM kepada Prof. Dr. Sukanto Reksohadiprodjo, M.Com. selaku Rektor UGM periode 1994-1998 pada tanggal 6 
Februari 1995 (Berita Acara Serah Terima Bangunan, 1995: 1). Pada saat pidato peresmian Gedung Auditorium UGM, Presiden Soeharto memberi nama Gedung Auditorium UGM dengan nama Grha Sabha Pramana dan sampai sekarang lebih dikenal dengan nama Gedung Grha Sabha Pramana UGM (Rekaman Arsip Kaset Peresmian Gedung Grha Sabha Pramana UGM Volume 1, 1994).

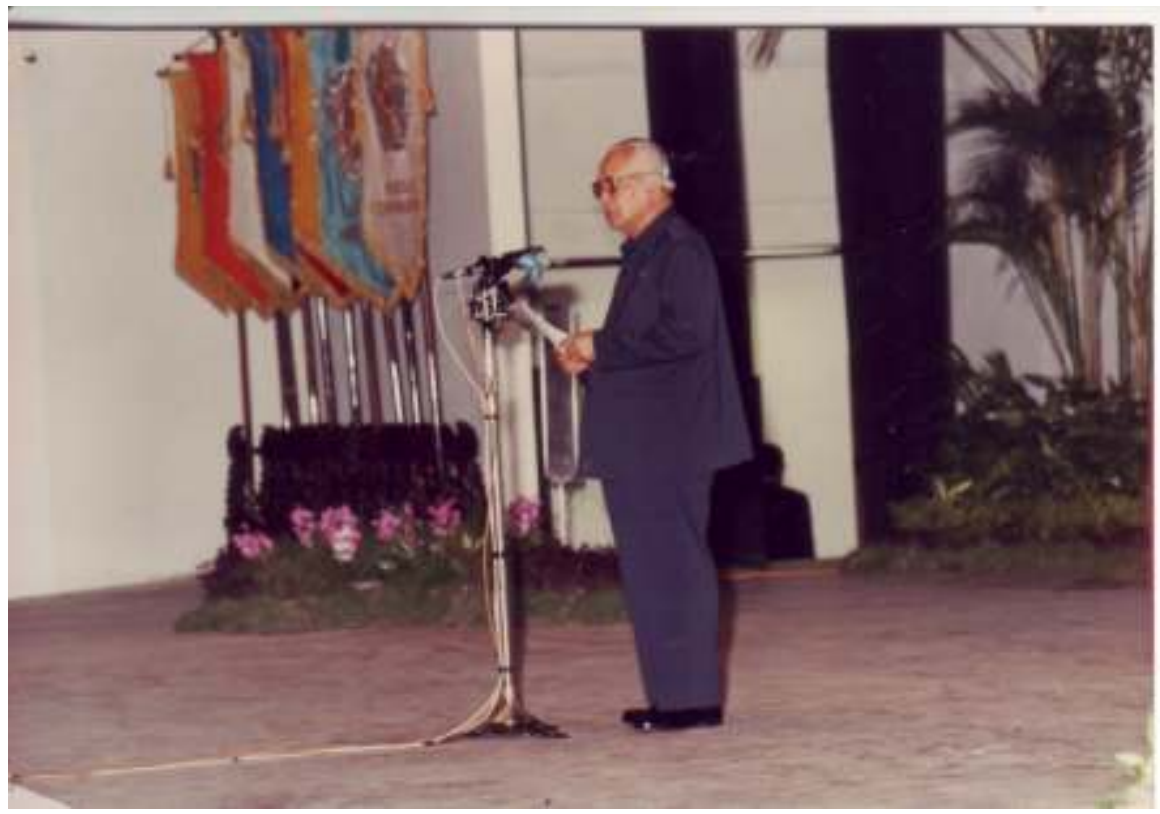

Foto 8

Sambutan Presiden Soeharto dalam acara peresmian Auditorium UGM.

(Sumber: AF3.IP.IG.1994.5F)

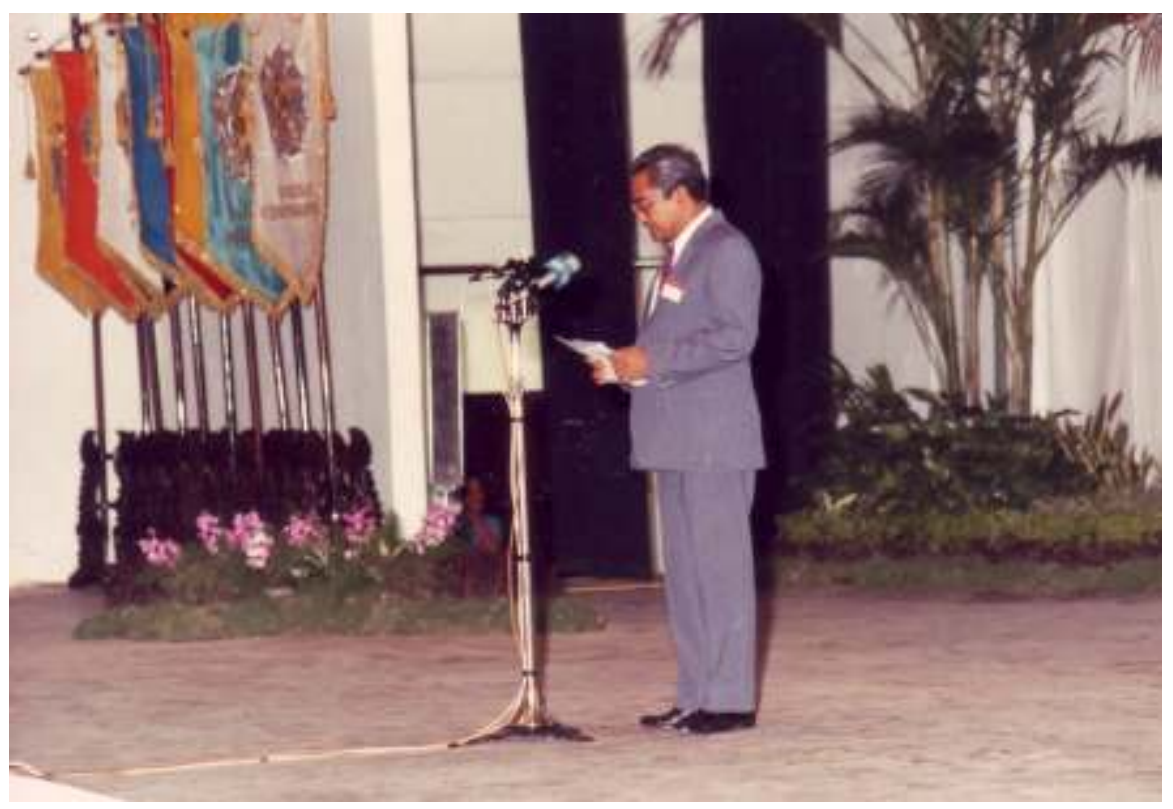

Foto 9

Sambutan Rektor UGM Prof. Dr. Soekanto Reksohadiprodjo, M.Com. dalam acara peresmian Auditorium UGM (Sumber: AF3.IP.IG.1994.5C) 


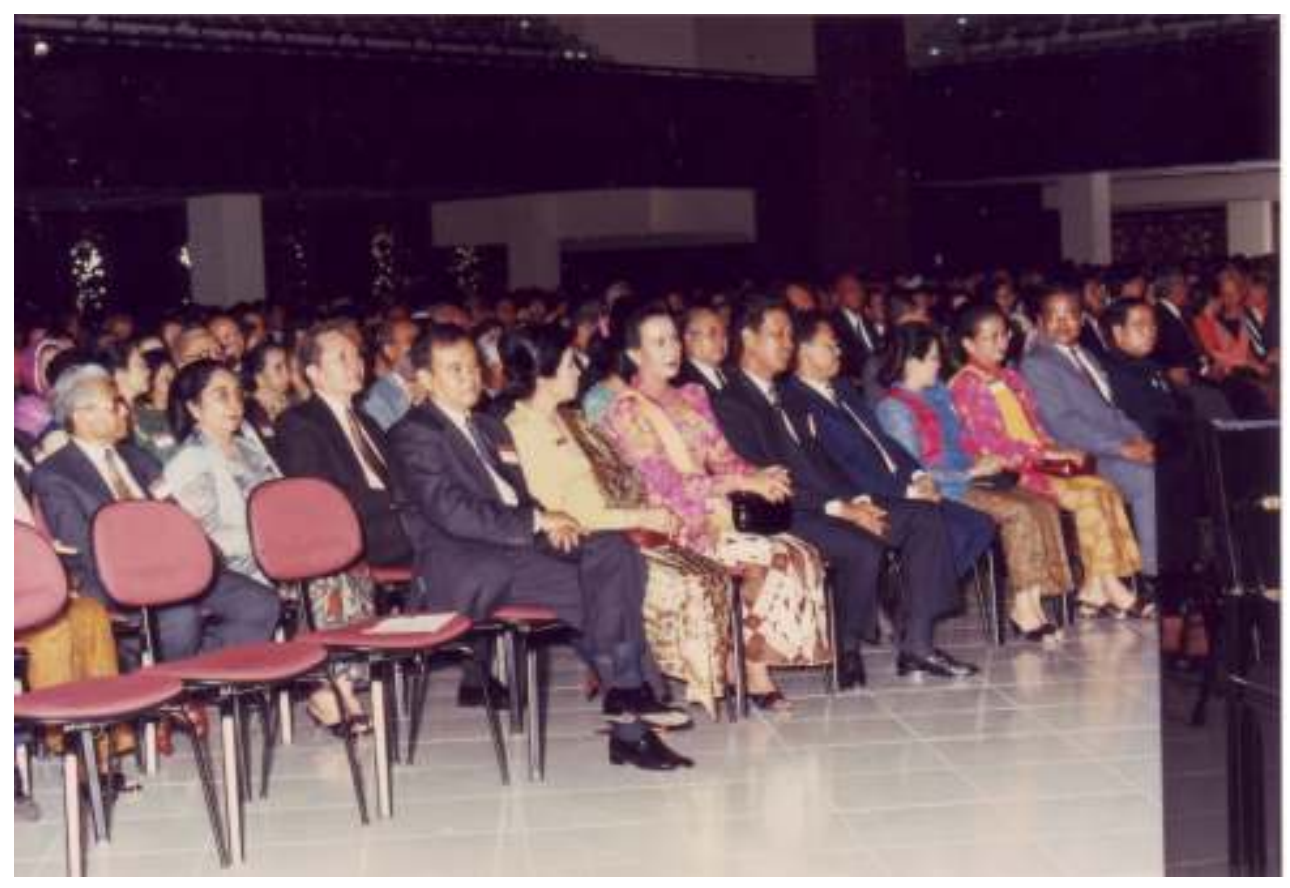

Foto 10

Para tamu undangan peresmian Grha Sabha Pramana UGM yang hadir, diantaranya, depan: Sri Sultan HB X, GKR Hemas, Rektor UGM, dan istri;

deretan kedua: Prof. Dr. T. Jacob beserta istri, Prof. Dr. Mochammad Adnan, M.Sc.

(Sumber: AF3/IP.IG/1994-5H)

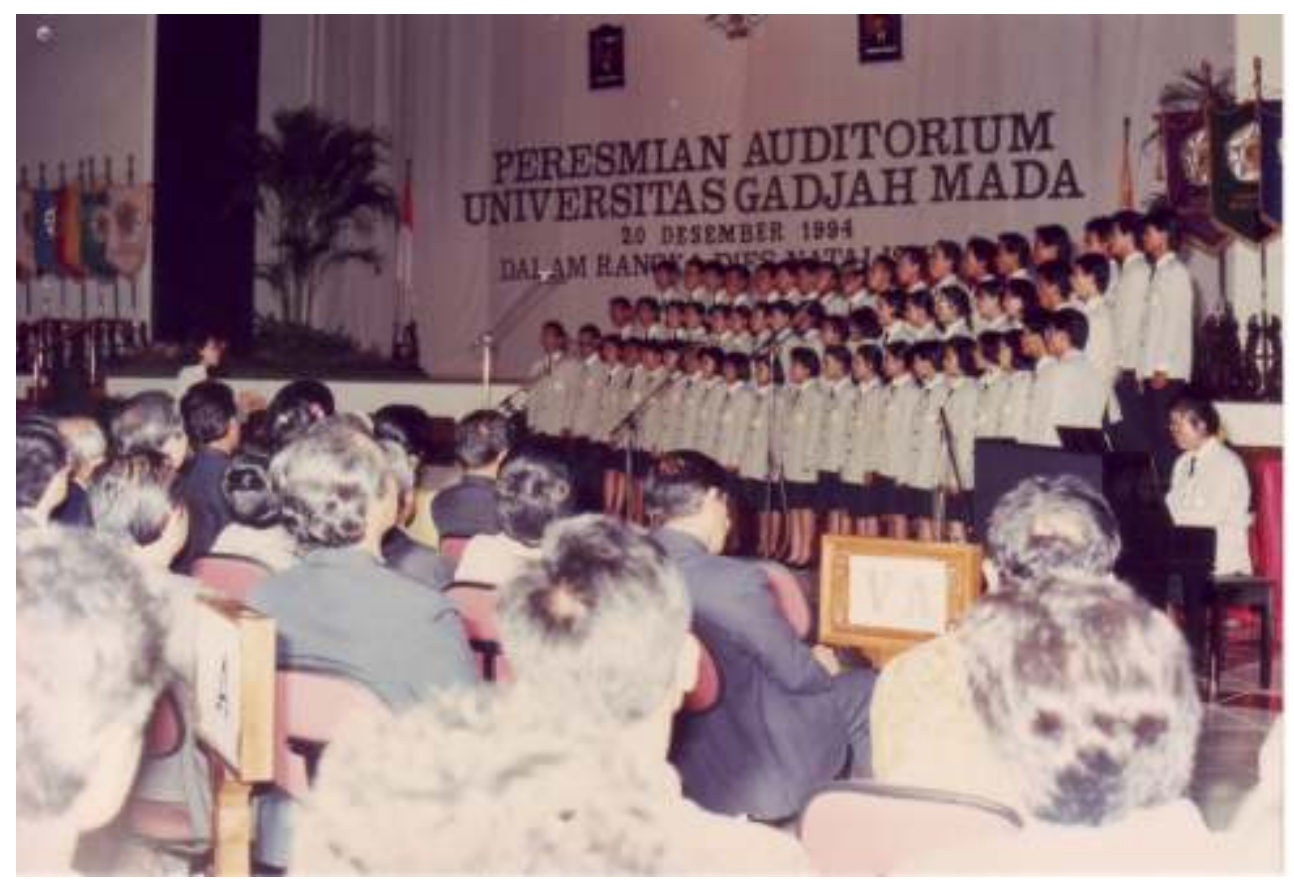

Foto 11

Paduan suara mahasiswa UGM sedang menghibur para tamu undangan pada Peresmian Auditorium UGM

(Sumber: AF3/IP.IG/1994-5H) 
IV. Perkembangan Pemanfaatan Auditorium UGM

Berdasarkan keterangan dari hasil wawancara dengan Hendrik Susanto, Awalnya fungsi utama Gedung Auditorium UGM digunakan untuk menunjang segala kegiatan akademik yang diselenggarakan oleh Universitas Gadjah Mada, antara lain digunakan untuk penyelenggaran wisuda mahasiswa Universitas Gadjah Mada, penyelenggaraan kuliah umum, penyelenggaran seminar, job fair dan segala penyelenggaran kegiatan akademik yang memiliki hubungan koordinasi langsung dengan pihak kampus. Selain itu mulai tahun 2009 setiap tahun di lapangan Gedung Grha Sabha Pramana ini digunakan untuk acara berskala nasional yaitu Aubade atau parade menyanyikan lagu-lagu nasional dan lagu mars perjuangan. Kegiatan yang bertajuk Aubade Pancasila ini melibatkan kurang lebih 5000 orang anggota paduan suara yang berasal dari siswa sekolah dasar, sekolah menengah, mahasiswa perguruan tinggi, anggota karangtaruna, anggota PKK, organisasi pemuda dan kelompok paduan suara Tionghoa. Peserta paduan suara sangat beragam, ada yang berumur 8 tahun hingga yang berumur 80 tahun. (Wawancara dengan Hendik Susanto Supervisor Grha Sabha Pramana UGM, 30 April 2018. Pukul 08.00).

Setelah diresmikan, salah satu kegiatan pemanfaatan aset yang dilakukan oleh Universitas Gadjah Mada adalah pemanfaatan gedung auditorium Grha Sabha Pramana (UU No 28 tahun 2002 tentang bangunan gedung). Gedung ini dimanfaatkan kepada publik dalam bentuk perjanjian sewa menyewa. Gedung Grha Sabha Pramana ini dapat dimanfaatkan oleh masyarakat umum yang ingin menyelenggarakan kegiatan-kegiatan yang membutuhkan ruangan dengan kapasitas besar. Kegiatan yang paling sering dilakukan oleh masyarakat umum antara lain; acara pernikahan, kegiatan wisuda SD-SMP-SMA, acara konser, dan seminar nasional. Selain itu setiap pagi dan

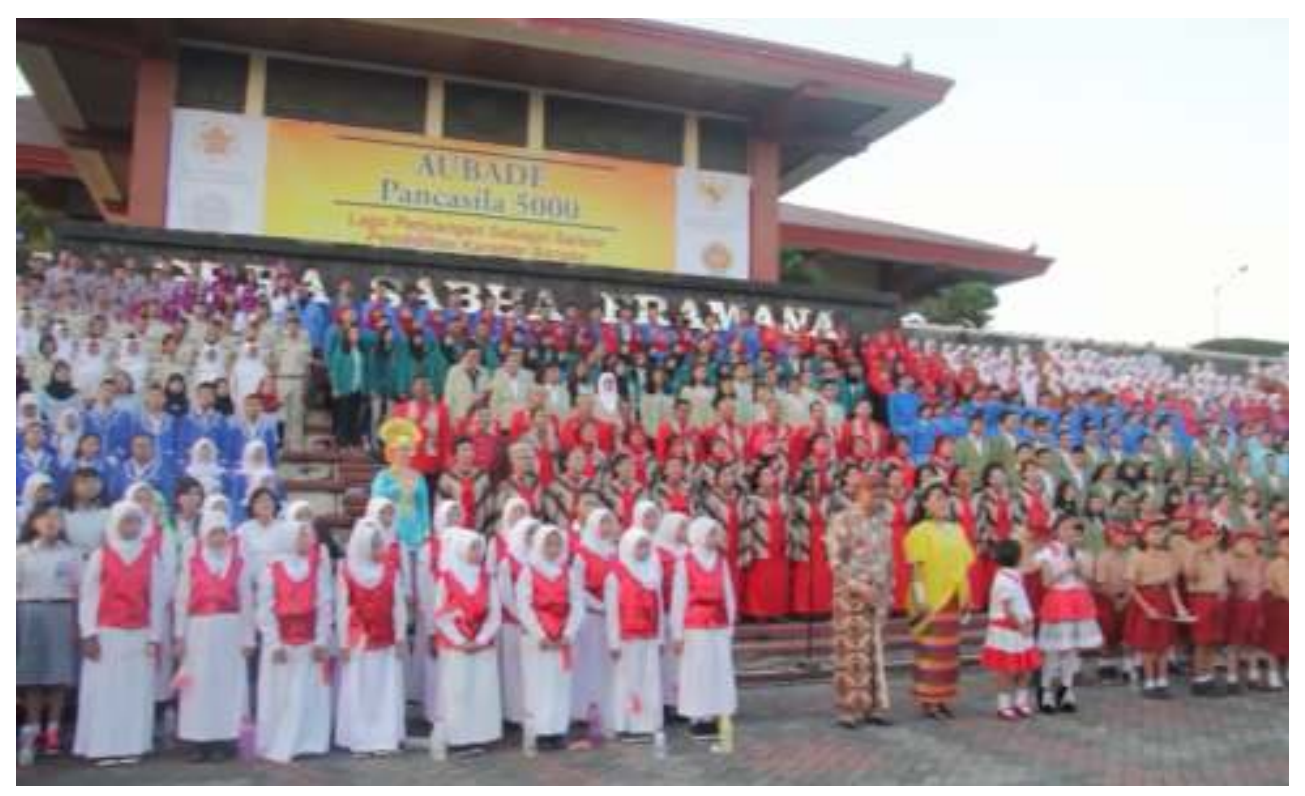

Foto 12

Foto Aubade Pancasila

(Sumber: Dokumen Humas UGM) 


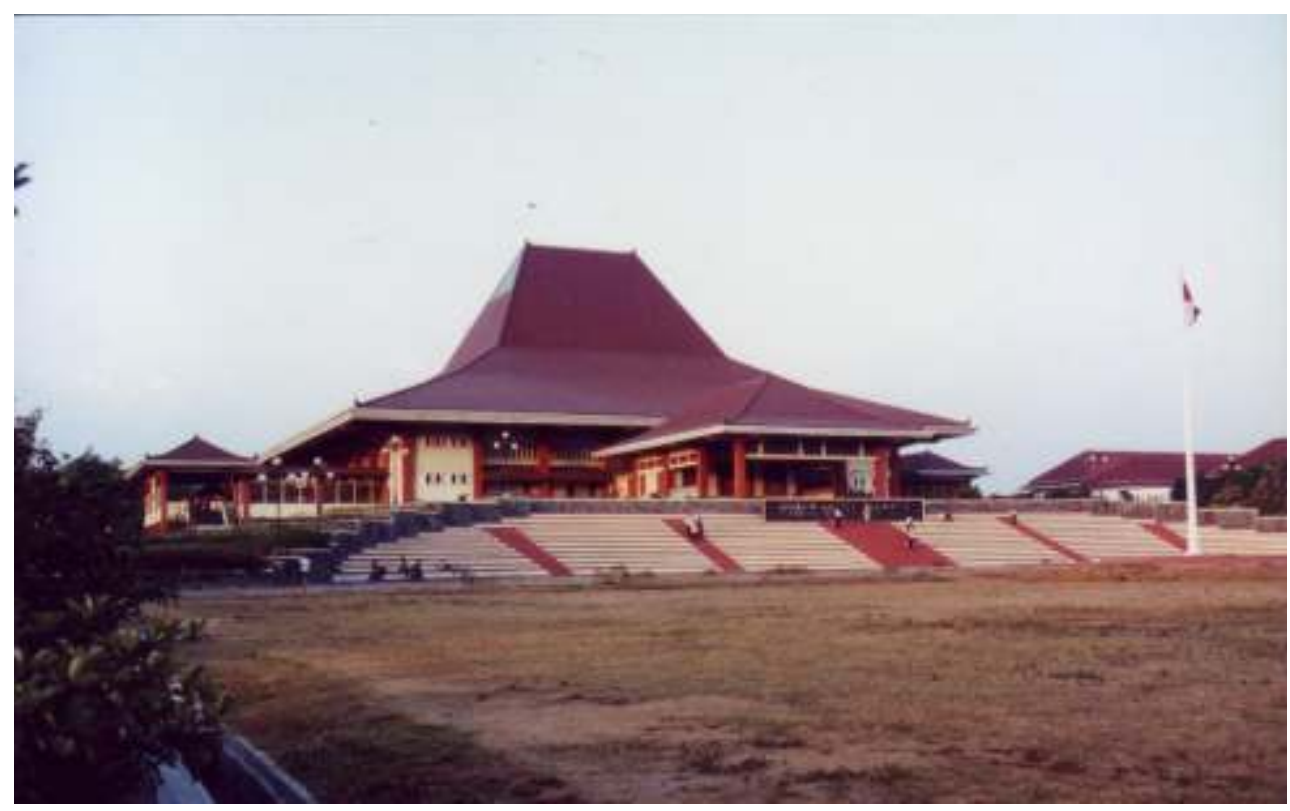

Foto 13

Gedung Grha Sabha Pramana sekarang

(Sumber: AF4.IP.IG.1997.2A)

sore hari di depan dan sekeliling Gedung Grha Sabha juga digunakan oleh mahasiswa dan masyarakat umum untuk ajang olah raga maupun untuk sekedar bersantai menikmati pemandangan. Mulai tahun 2015 Grha Sabha Pramana sebagai salah satu aset yang dikelola Gama Residence UGM, lembaga yang ditugasi mengelola berbagai komersial di lingkungan UGM (Wawancara dengan Hendik Susanto Supervisor Grha Sabha Pramana UGM, 30 April 2018. Pukul 08.00).

\section{KESIMPULAN}

Gedung Auditorium UGM yang lebih dikenal dengan nama Gedung Grha Sabha Pramana ini adalah sebuah bangunan dengan atap joglo yang berada di tengah-tengah kampus Universitas Gadjah Mada. Pembangunan gedung ini menganut konsep arsitektur Jawa di daerah pusat kampus dengan urutan hierarki: Alun-alun (sisa lahan di depan Auditorium), Pendopo
(Auditorium), Pringgitan (Perpustakaan), dan Dalem (Kantor Pusat UGM). Ketiga gedung tersebut sebagai posisi sentral dan mencerminkan karakter kampus UGM, kesatuan yang kuat kompak, berwibawa dan monumental.

Mencermati dari berbagai sumber tentang sejarah pendirian Gedung Auditorium UGM menunjukkan bahwa perancangan gedung Auditorium UGM telah didesain sangat bagus dan berkesan bersahabat dengan alam dan terbuka kepada sesama sehingga bisa bermanfaat secara maksimal bagi sivitas akademika UGM maupun masyarakat pada umumnya. Selain itu, desain bangunan ini penuh makna filosofi yang sangat dalam, hal ini bisa dilihat dari letak gedung, desain gedung, dan ornament-ornamen ukiran yang ada dalam gedung. Desain tersebut menunjukkan bahwa UGM memiliki visi, misi, dan harapan kedepan yang jelas yang digambarkan dalam simbul simbul tersebut. Pemanfaatan Gedung Auditorium ini awalnya 
untuk acara intern UGM, namun seiring perkembangan waktu gedung ini sekarang bisa dimanfaatkan oleh masyarakat umum dengan cara sewa.

Saran penulis, penutupan akses jalan menuju gedung perpustakaan dan Gedung Pusat UGM ketika acara wisuda perlu kaji ulang, solusinya dengan dibuatkan jalur khusus disebelah barat gedung supaya pegawai yang ingin berangkat kerja saat proses wisuda tidak terganggu dengan proses wisuda tersebut.

Penelitian ini menyajikan data primer yang bersumber pada khasanah arsip yang tersimpan di Arsip UGM dengan kajian sejarah tentang Gedung Auditorium/Grha Sabha Pramana UGM. Sumber-sumber sejarah terkait Gedung Auditorium UGM tersebut berupa arsip tekstual, arsip foto, arsip rekaman suara/kaset, kliping media dan beberapa terbitan di UGM serta wawancara.

Penyajian informasi arsip tentang suatu hal berdasarkan tema tertentu atau suatu peristiwa dalam bidang kearsipan disebut sebagai guide tematis, sehingga penelitian ini bisa disebut juga menyajikan guide tematis tentang sejarah singkat Gedung Auditorium UGM dan perkembangannya. Penulis berusaha menyajikan informasi tentang sejarah Gedung ini sehingga memudahkan para peneliti maupun pengguna arsip dalam menemukan arsip berdasarkan tema tertentu.

\section{DAFTAR PUSTAKA}

Alan, Male. 2007. Illustration: A Theoritical \& Contextual Perspective. SA: AVA Publishing.

Burke, Peter. 1993. History and Social Theory, Cetakan Pertama, Cornell University Press, Zulfami, 2003 Sejarah Teori Sosial, Edisi Kedua. Jakarta: Yayasan Obor Indonesia.

Dipohusodo, Istimawan. 1996. Manajemen Proyek dan Konstruksi Jilid 2. Yogyakarta: Kanisius

Feilden, Bernard.M. 1982. Conservation of Historic Building. ButterworthHeinemann Ltd.

Geddes and Grosset. 2003. Webster's universal dictionary and thesaurus. Scotland.

Hasanah, Neneng Uswatun. 2016. Sejarah Bangunan Indonesia Karya Arsitek Belanda. Surabaya

Kanumoyoso, Bondan. 2017. Metode Sejarah. Jakarta: Kemendikbud.

Kartodirdjo, Sartono. 1982. Pemikiran dan Perkembangan Historiografi. Jakarta: PT Gramedia

Koentjaraningrat. 1974. Pengantar Antropologi. Jakarta: PenerbitAksara Baru.

Kuntowijoyo. 2001. Pengantar Ilmu Sejarah. Cet. ke-4.Yogyakarta: Yayasan Bentang Budaya

Munajat, Ade. 2004. Sejarah 1. Bandung: Remaja Rosdakarya.

Panero, Julius \& Zelnik, Martin. 2003. Dimensi Manusia dan Ruang Interior. Jakarta: Erlangga.

Soewadji, Jusuf. 2012. Pengantar Metodologi Penelitian. Jakarta: Mitra Wacana Media.

Undang-Undang Nomor 28 tahun 2002 tentang Bangunan Gedung. 


\section{Sumber Arsip}

1. Laporan Perancangan Pekerjaan Pembangunan Gedung Auditorium Universitas Gadjah Mada Proyek Peningkatan Perguruan Tinggi UGM (P2TUGM) Bank Dunia XXI (AS4/IP.TG.01/6)

2. Laporan Pembangunan Gedung Auditorium UGM oleh Tim Pengelola Pembangunan Fisik Proyek Peningkatan Perguruan Tinggi P2T-UGM Gedung Auditorium. (AS4/IP.TG.01/6)

3. Berita Acara Serah Terima Bangunan Auditorium "Graha Sabha Prama" Luas 11.070 M 2 U G M N : P $2 \mathrm{~T}$ UGM/180/BA/II/95 tanggal 6 Februari 1995 (AS6/IP.TG.01/44)

4. Berita Acara Penjelasan Pekerjaan Pembangunan Gedung Auditorium UGM No: P2T-UGM/184A/BA/I/93 tanggal 11 Januari 1993 (AS6/IP.TG.01/21.2)

5. Kliping Media Mei 1993 (AS/PA.KM/76)

6. Kliping Media Mei 1993 (AS/PA.KM/77)

7. Terbitan UGM Berita Kagama 1993 (AS5/PA.BK/17)

8. Terbitan UGM Warta UGM Agustus 1993 (AS/PA.WU/2)

9. Foto Gedung GSP yang belum jadi tampak dari depan sebelah kiri (Sumber: AF3.IP.IG.1994.1G)

10. Foto gedung GSP tampak dari depan samping kanan (AF3/IP.IG/1995-2A)

11. Foto Sambutan Presiden Soeharto dalam acara peresmian Auditorium UGM. (Sumber:AF3.IP.IG.1994.5F)

12. Foto Sambutan Rektor UGM Prof. Dr. Soekanto Reksohadiprodjo, M.Com. dalam acara peresmian Auditorium UGM (Sumber: AF3.IP.IG.1994.5C)

13. Foto Para tamu undangan peresmian Grha Sabha Pramana UGM (Sumber: AF3/IP.IG/1994-5H)
14. Foto Paduan suara mahasiswa UGM sedang menghibur para tamu undangan pada Peresmian Auditorium UGM (Sumber: AF3/IP.IG/1994-5H)

15. Foto (Sumber:AF4.IP.IG.1997.2A)

16. Foto pintu utama Gedung Grha Sabha Pramana lantai 1 (Fotografer: Heri Santosa. GSP, 7 Juni 2018)

17. Foto pintu utama Gedung Grha Sabha Pramana lantai 2 (Fotografer: Heri Santosa. GSP, 7 Juni 2018)

18. Foto Pintu masuk kanan dan kiri Gedung Grha Sabha Pramana lantai 2 (Fotografer: Heri Santosa. GSP, 7 Juni 2018)

19. Foto pintu lipat Gedung Grha Sabha Pramana lantai 2 (Fotografer: Heri Santosa. GSP, 7 Juni 2018)

20. Foto Ukiran diatas panggung Gedung Grha Sabha Pramana lantai 2 (Fotografer: Heri Santosa. GSP, 7 Juni 2018)

21. Foto Ukiran diatas panggung Gedung Grha Sabha Pramana lantai 2 (Fotografer: Heri Santosa. GSP, 7 Juni 2018)

22. Arsip rekaman suara/ kaset peresmian Gedung Grha Sabha Pramana UGM Volume $1,1994)$.

\section{Narasumber}

Susanto, Hendrik. 2018. Sejarah Grha Sabha Pramana UGM. Wawancara oleh Heri Santosa, (UGM, 30 April, pukul 08.00)

\section{Sumber Online}

Amstrophel13architect. 2013. Seputar Arsitektur. https://amstrophel13architect. wordpress.com/2013/04/24/proses-design/; (diakses tanggal 18 Mei 2018)

(Amstrophel13architect. 2013. Seputar Arsitektur https://amstrophel13architect. wordpress.com/2013/04/24/hal-yang-perludiperhatikan-dalam-proses-perancangan/; diakses tanggal $18 \mathrm{Mei}$ )

Setiawan, Ebta.2012-2018. Kamus Besar Bahasa In d on e sia (K B B I). h t t p s : / / www.kbbi.web.id/bahan-2 ; (Diakses tanggal 8 Mei2018) 